\title{
Identification of human myometrial target genes of the cAMP pathway: the role of cAMP-response element binding (CREB) and modulator (CREM $\alpha$ and $\left.\mathrm{CREM} \tau_{2} \alpha\right)$ proteins
}

\author{
Jarrod Bailey, Alison J Tyson-Capper (née Pollard), Kate Gilmore, Stephen C Robson and \\ G Nicholas Europe-Finner
}

School of Surgical and Reproductive Sciences, The Medical School, University of Newcastle upon Tyne, UK

(Requests for offprints should be addressed to J Bailey, School of Surgical and Reproductive Sciences (Obstetrics and Gynaecology), 3rd Floor, William Leech Building, Faculty of Medical Sciences, Framlington Place, Newcastle upon Tyne NE2 4HH, UK; Email: jarrod.bailey@ncl.ac.uk)

\begin{abstract}
cAMP-response element (CRE) binding (CREB) and modulator (CREM) proteins, activated by protein kinase A-mediated phosphorylation, bind as homo- and heterodimers to promoters containing CRE and activator protein 1 (AP-1) sites to alter target-gene expression. We have previously reported differential expression of CREB and CREM splice variants $\mathrm{CREM} \alpha$ and $\mathrm{CREM} \tau_{2} \alpha$ in human myometrium during pregnancy and labour. Via microarray studies with cultured myometrial cells stably transfected with CREB, CREM $\alpha$ and CREM $\tau_{2} \alpha$ cDNAs, CREB affected the expression of 958 genes; 522 being up-regulated and 436 down-regulated. CREM $\alpha$ altered the expression of 118 genes; 71 were increased and 47 decreased. CREM $\tau_{2} \alpha$ affected 220 genes; 148 were activated and 72 repressed. Notably, genes affected by CREB, CREM $\alpha$ and CREM $\tau_{2} \alpha$ belong to largely discrete groups: less than $9 \%$ were affected by more than one factor. Genes involved in regulation of cell death and apoptosis, growth and maintenance, signal transduction, physiological and developmental processes, protein kinase cascades, extracellular matrix, cytoskeleton, cell-cycle regulation, transport, and a variety of enzymes, intracellular components and nucleic acid-binding proteins have been described, many of which are involved in the modulation of myometrial activity during pregnancy and parturition.
\end{abstract}

Journal of Molecular Endocrinology (2005) 34, 1-17

\section{Introduction}

Many signalling pathways and cascades, comprising a wide variety of hormone-, growth factor-, stress- and inflammation-mediated stimuli, crosstalk and converge to mediate the activation of the ubiquitous cAMPresponse element (CRE) binding (CREB) and modulator (CREM) proteins (De Cesare et al. 1999), via phosphorylation at serine residues 133 and 117 respectively (Gonzalez \& Montminy 1989, de Groot et al. 1993). This family of transcription factors consists of a large number of protein isoforms generated from an array of alternatively spliced transcripts. Constituent exons bestow upon these splice variants different facets of functionality, including a leucine zipper domain for dimerization with other related proteins, a basic region for DNA binding, two glutamine-rich domains involved in trans-activation, and a kinase-inducible domain (termed a P-box or KID) as a site for phosphorylation and activation (Sun et al. 1992, Walker et al. 1994, Habener et al. 1995, Sanborn et al. 1997). Each CREB/CREM isoform therefore possesses trans-activation and/or trans-repression properties depending on the exonic configuration of their mRNAs. In total, seven alternatively spliced isoforms of CREB have been identified (Don and Stelzer 2002), and a multitude of CREM isoforms arising not only by alternative splicing, but also due to alternative promoters, different transcription- and translation-initiation sites, and changes in stability due to variant poly-A sites (Sanborn 2000a).

CREB and CREM are members of the basic region leucine-zipper (bZIP) family of transcription factors (Landschulz et al. 1988, Ziff 1990), which also includes the activating transcription factor (ATF) proteins and Jun and Fos. These proteins are able to function as homo- and/or hetero-dimers (Sassone-Corsi 1988, Hai et al. 1989, Hai and Curran 1991, Borrelli et al. 1992), and regulate the transcription of downstream-affected genes via binding to regulatory motifs in their promoter regions such as the CRE (consensus sequence, 5'TGACGTCA- $3^{\prime}$ ) and the TPA-response element (TRE) or activator protein 1 (AP-1) site (consensus sequence, 5'-TGAGTCA-3'; Xie et al. 1995). Binding of these motifs can occur irrespective of the phosphorylation state of the constituent dimer proteins, and indeed is one method of inhibition of transcription of cAMPresponsive genes.

Although activation of CREB and CREM can occur for example via (i) synaptic activity through calmodulin, (ii) growth factor binding through extracellular signal- 
regulated kinase (ERK) and (iii) stress and inflammatory cytokine action through p38, perhaps the major determinant is the binding of hormone ligands to G-protein-coupled receptors (GPCRs; Servillo et al. 2002). This causes a rise in the intracellular level of cAMP due to activation of adenylate cyclase, which in turn promotes the phosphorylation of CREB and CREM factors via protein kinase A (PKA). Other components of the cAMP signaling pathway are often up- or down-regulated to affect cAMP levels, notably hormonal ligands that bind to the GPCRs (Zuo et al. 1994), the receptors themselves (Dong et al. 1999), phosphodiesterase (Kofinas et al. 1990) and the stimulatory protein $G_{\alpha \mathrm{s}}$ (Europe-Finner et al. 1993, 1994, Lopez-Bernal et al. 1995). Increased expression of the latter is known to increase constitutive as well as stimulated cAMP accumulation, and augment distal events such as transcription factor phosphorylation and cAMP-responsive gene expression (Yang et al. 1997). Phosphorylated dimers of the CREB/CREM family are then able to bind to the CREB-binding protein $(\mathrm{CBP}) / \mathrm{p} 300$ co-activator protein, which in turn recruits the basal transcriptional machinery to initiate gene expression.

Transcripts of the CREB and CREM genes are present in all human tissues examined so far, but appear to be particularly important in the heart where they regulate cardiac myocyte function (Fentzke et al. 1998), in the immune system where they are involved in the development and function of $\mathrm{T}$ lymphocytes (Muller et al. 1998, Haus-Seuffert and Meisterernst 2000), in the brain where they have been implicated in the regulation of long-term memory and the circadian clock (SassoneCorsi 1998), the testes where they orchestrate spermatogenesis (Don and Stelzer 2002) and the uterus where there is strong evidence for their roles in the regulation of uterine contractility (Bailey et al. 2000, 2002). In the latter context, an increased level of cAMP in human myometrial smooth-muscle cells during pregnancy has been reported (Europe-Finner et al. 1993, 1994), potentiated by altered expression of various components of the cAMP signalling pathway, in particular $G_{\alpha s}$. Subsequently, we have reported the differential expression of specific CREB/CREM isoforms in this tissue during gestation, namely phosphorylated full-length CREB, CREM $\tau_{2} \alpha$ and CREM $\alpha$ proteins (Bailey et al. 2000, 2002), and demonstrated their ability to bind CRE-containing oligonucleotides and activate and/or repress reporter-gene transcription. The change in expression of these factors represents a major switch from the expression of the CREB activator to the CREM $\alpha$ repressor protein (Fig. la), a switch also well characterized in the testes during spermatogenesis (Walker et al. 1996, Foulkes and Sassone-Corsi 1992). Furthermore, the pre-mRNA splicing mechanisms within myometrial cells appear to switch from favouring the production of the alternatively spliced CREM $\tau_{2} \alpha$ activator that decreases sequentially through the nonpregnant, pregnant non-labouring and labouring phases, to the CREM $\alpha$ repressor protein that proceeds from zero expression in the non-pregnant uterus to a high level of expression in the labouring myometrium (Fig. 1b). To further characterize these factors, and elucidate the molecular mechanisms affecting myometrial gene expression, we have created stably transfected cell lines with plasmid constructs expressing the individual CREB and CREM proteins, and made use of microarray and semi-quantitative (SQ)/real-time reverse transcriptase (RT)-PCR experiments to identify downstream target genes that may be under their transcriptional control.

\section{Materials and methods}

\section{Human myometrial tissue collection}

Human myometrial tissue biopsies were collected from pregnant non-labouring $(\mathrm{P})$ women at elective Caesarean section and from non-pregnant (NP) premenopausal women (ages 32-46 years) at hysterectomies performed for benign gynaecological disorders such as menorrhagia or dysmenorrhoea. The myometrial samples were snap-frozen in liquid nitrogen and stored at $-70{ }^{\circ} \mathrm{C}$. Written consent was obtained from all women and ethical approval for the study was granted by the Newcastle and North Tyneside Health Authority Ethics Committee.

\section{Establishment of stable myometrial cell lines}

Primary cultures of human myometrial cells were initiated by treating small pieces of $\mathrm{P}$ myometrium with collagenase solution $(1 \mathrm{mg} / \mathrm{ml}$ collagenase, $0.02 \mathrm{mg} / \mathrm{ml}$ DNase, $0.2 \mathrm{mg} / \mathrm{ml}$ trypsin inhibitor, elastase and BSA fraction $\mathrm{V}$, in Hank's balanced salt solution free of $\mathrm{Ca}^{2+}$ and $\mathrm{Mg}^{2+}$ ions). Samples were incubated with gentle shaking for $4 \mathrm{~h}$, then transferred to a new tube to which $5 \mathrm{ml}$ complete medium plus $10 \%$ fetal calf serum had been added. After centrifugation at $1000 \boldsymbol{g}$ for $10 \mathrm{~min}$, the supernatant was decanted and discarded, and the cells resuspended in $15 \mathrm{ml}$ fresh complete medium plus $10 \%$ fetal calf serum, and the cells seeded into flasks. After incubation at $37^{\circ} \mathrm{C}$ for $1 \mathrm{~h}$ to allow fibroblast attachment, the medium, now containing primarily myometrial cells with few contaminating fibroblasts, was transferred to new flasks and incubated for $24 \mathrm{~h}$ at $37^{\circ} \mathrm{C}$. The growth medium was then replaced to inhibit fibroblast growth, with MEM D-Valine medium (Gibco) plus $10 \%$ fetal calf serum, containing $50 \mathrm{U} / \mathrm{ml}$ penicillin and $50 \mu \mathrm{g} / \mathrm{ml}$ streptomycin. Growth medium was replaced with fresh medium every $2-3$ days, and after reaching confluence cells were subcultured at a ratio of $1: 3$. 
(a)

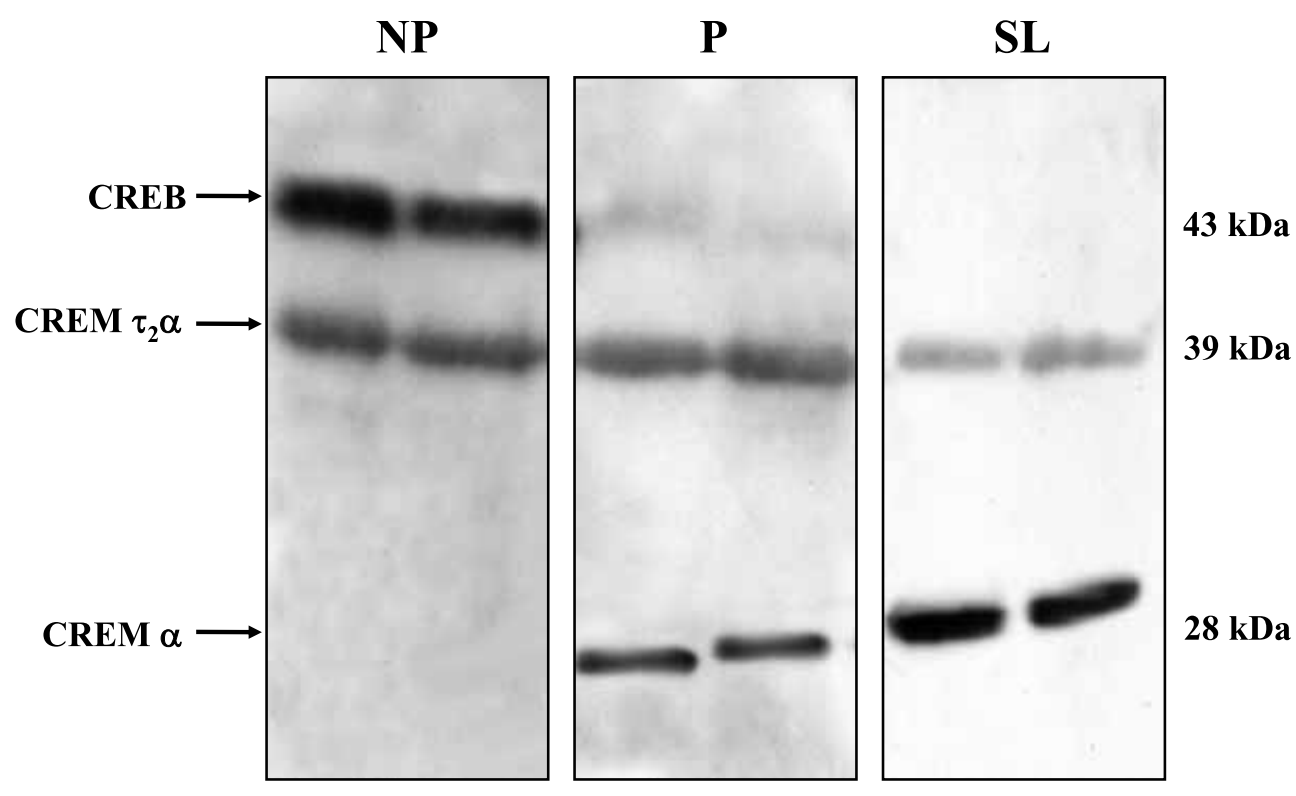

(b)

CREM gene
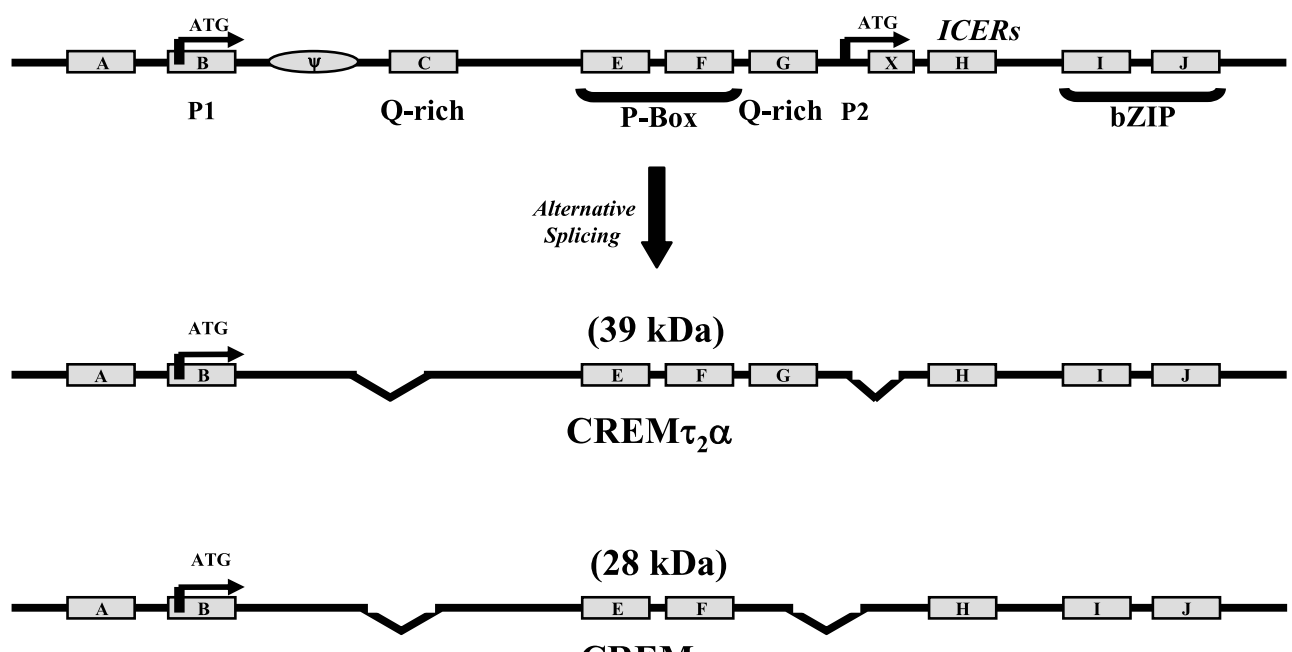

CREM $\alpha$

Figure 1 (a) Immunodetection with CREM-1 antibody (Santa Cruz Biotechnology) of CREB and CREM in human lower uterine myometrial samples from non-pregnant (NP), pregnant non-labouring (P) and spontaneously labouring (SL) women revealed three species of protein; a $43 \mathrm{kDa}$ phosphorylated CREB protein highly expressed in the NP state but significantly down-regulated in $\mathrm{P}$ and SL tissue, a $28 \mathrm{kDa}$ CREM $\alpha$ isoform absent from NP myometrium but up-regulated in $\mathrm{P}$ and further again in SL, and a $39 \mathrm{kDa}$ $\mathrm{CREM} \tau_{2} \alpha$ isoform chiefly expressed in NP tissue then down-regulated in P and SL. This blot reveals a dramatic switch in expression from the expression of the CREB transcriptional activator protein to the expression of the CREM $\alpha$ transcriptional repressor in the transition from the NP to the P state, and also illustrates a change in the RNA splicing machinery to favour the production of CREM $\alpha$ in preference to $\mathrm{CREM} \tau_{2} \alpha$. Reproduced from Bailey et al. 2000. (b) Splicing mechanisms in the myometrium shift expression from the CREM $\tau_{2} \alpha$ trans-activator/trans-repressor in the non-pregnant uterus to the CREM $\alpha$ trans-repressor during pregnancy and labour. Exons are shown by rectangles and the elipse represents a 'novel module' present in a small number of CREM splice variants, containing an in-frame stop codon. Q-rich, glutamine-rich domains involved in trans-activation; P-Box, kinase-inducible domain; $\mathrm{P} 1$ and $\mathrm{P} 2$, alternative promoters; ICERs, inducible cAMP early repressors transcribed from the P2 promoter. $\mathrm{CREM} \tau_{2} \alpha$ lacks exon $\mathrm{C}$ and functions as an activator or repressor depending upon promoter context and cell type. CREM $\alpha$ lacks both exons encoding $Q$-rich domains ( $C$ and $G)$, and except in exceptional circumstances acts as a repressor of transcription. 
Full-length CREB was cloned into pCDNA3.1/V5 HisTOPO (Invitrogen) via RT-PGR using mRNA from pooled NP tissue $(n=6)$ as a template, and primers (F) 5'-ATGACGATGGAATCTGGAGGCGAGAAC-3' and (R) 5'-TTAATGTGATTTGTGGGAGTAAAG GTC-3', where $\mathrm{F}$ is forward primer and $\mathrm{R}$ is reverse primer. CREM $\tau_{2} \alpha$ and CREM $\alpha$ plasmids were constructed as described previously (Bailey et al. 2002). Transfections were performed upon low-passagenumber myometrial cells (passages 2 or 3 ) at $70 \%$ confluence using $4 \mu \mathrm{l}$ Mirus TransIT-LT1 lipid-based transfection reagent (Cambridge Bioscience, Cambridge, $\mathrm{UK})$ per $1 \mu \mathrm{g}$ plasmid. Typically, $6 \mu \mathrm{g}$ plasmid was used per transfection, mixed with $24 \mu \mathrm{l}$ LT-1 reagent and $200 \mu \mathrm{l}$ serum-free medium and incubated at room temperature for $5 \mathrm{~min}$. This complex was added to the cells and incubated at $37^{\circ} \mathrm{C}$ for $4 \mathrm{~h}$, after which time it was removed and fresh medium (plus serum) added. Incubation at $37^{\circ} \mathrm{C}$ was continued for $48 \mathrm{~h}$, after which time the selective agent G418 was added to a final concentration of $80 \mu \mathrm{g} / \mathrm{ml}$. Colonies were subsequently cloned by limiting dilution, and maintained with selective pressure in an increased final G418 concentration of $250 \mu \mathrm{g} / \mathrm{ml}$.

\section{Cell staining/immunocytochemistry}

Cultured myometrial cells were stained to allow morphological examination using haematoxylin and eosin stains. Cells grown on coverslips were rinsed with $1 \times$ PBS, fixed in cold methanol for $10 \mathrm{~min}$, washed with water and then exposed to haematoxylin for $1 \mathrm{~min}$. Following a quick water wash, cells were exposed to Scott's water $\left(0.04 \mathrm{M} \mathrm{NaCO}_{3} / 0.08 \mathrm{M} \mathrm{MgSO}_{4}\right)$ for $1 \mathrm{~min}$. Another water wash was performed, then the cells were incubated in eosin stain for $2 \mathrm{~min}$. After a final brief wash in water, the slips were allowed to dry and mounted in DPX resin on microscope slides for viewing.

To determine the level of fibroblast contamination in the smooth-muscle cell cultures, immunocytochemistry was performed using fibroblast antigen (Ab-1; Oncogene Research Products, San Diego, CA, USA; Saalbach et al. 1997) and the DAKO ChemMate APAAP detection kit with a Vector Blue Alkaline Phosphatase Substrate Kit III (Vector Laboratories, Burlingame, CA, USA). Cells were cultured on coverslips and fixed as above, then incubated in normal rabbit serum for $10 \mathrm{~min}$. After a brief rinse with Tris-buffered saline (TBS), cells were incubated in Ab-1 primary antibody for $1 \mathrm{~h}$ at a $50 \mu \mathrm{l} / \mathrm{ml}$ dilution $(10 \mu \mathrm{g} / \mathrm{ml}$ final concentration) at room temperature. After three 5-min rinses in $1 \times$ TBS, cells were exposed to the secondary-link antibody for $45 \mathrm{~min}$. Following three more 5 -min rinses in $1 \times$ TBS, the cells were incubated in APAAP for $20 \mathrm{~min}$, followed by another round of washing in $1 \times$ TBS. One drop of the Levamisole chromagen was then added to the cells, and colour development was monitored microscopically. Chromagenesis was halted by rinsing with water, and fibroblast contamination was assessed by microscopic examination and cell counting.

\section{RNA isolation}

Total RNA was isolated from approximately $1 \times 10^{7}$ cells using TRI-Reagent (Sigma-Aldrich) according to the manufacturer's protocol. The resulting pellet was resuspended in $100 \mu \mathrm{l}$ RNase-free water, and incubated at $55^{\circ} \mathrm{C}$ for $10 \mathrm{~min}$ to aid this process. This total RNA was then applied to an RNeasy mini-column (Qiagen), and subjected to RNase-free DNase treatment using the RNase-free DNase set (Qiagen). The remainder of the manufacturer's protocol was then followed for RNA cleanup, eluting with $25 \mu \mathrm{l}$ RNase-free water. Total RNA was quantified by spectrophotometry, and used for microarray analysis.

\section{Confirmation of CREB/CREM expression levels in stably transfected cell lines}

Levels of CREB, CREM $\alpha$ and CREM $\tau_{2} \alpha$ expression in stably transfected cell lines were examined and compared with one another by SQ RT-PGR using the Superscript one-step RT-PCR system (Invitrogen) in a total volume of $25 \mu \mathrm{l}$ with $5 \%$ (v/v) RNaseOUT (Invitrogen) RNase inhibitor, and $100 \mathrm{ng}$ total RNA template prepared as described above. Primers for CREB and CREM were as described above, and reaction conditions as follow. Reverse-transcription step, $50{ }^{\circ} \mathrm{C}$ for $30 \mathrm{~min}, 94^{\circ} \mathrm{C}$ for $2 \mathrm{~min}$; amplification step, 40 cycles (CREB) $/ 30$ cycles (CREM) of $94^{\circ} \mathrm{C}$ for $15 \mathrm{~s}$, $63{ }^{\circ} \mathrm{C}(\mathrm{CREB})$ or $58{ }^{\circ} \mathrm{C}(\mathrm{CREM})$ for $30 \mathrm{~s}$, and $68{ }^{\circ} \mathrm{C}$ for $1 \mathrm{~min}$, followed by $68^{\circ} \mathrm{C}$ for $9 \mathrm{~min} .5 \mu \mathrm{l}$ of each reaction was subjected to agarose gel electrophoresis; RNA samples from those colonies displaying the highest CREB/CREM expression were selected for microarray analysis.

\section{Affymetrix microarray analysis}

\section{Target preparation}

A total of $10 \mu \mathrm{g}$ RNA were used for each target. Each sample was used as a basis to synthesize double-stranded cDNA, which in turn was used to synthesize biotinlabelled cRNA for hybridization to the microarray chips. The Affymetrix protocol was followed, and the steps are summarized briefly here.

\section{cDNA synthesis}

First-strand cDNA synthesis was achieved using the SuperScript Choice system (Invitrogen) and the 
GeneChip T7-Oligo(dT) primer at $42{ }^{\circ} \mathrm{C}$ for $1 \mathrm{~h}$. Second-strand cDNA was synthesized from this using Escherichia coli DNA ligase, polymerase I and RNase $\mathrm{H}$ at $16{ }^{\circ} \mathrm{C}$ for $2 \mathrm{~h}$.

\section{Synthesis of biotin-labelled cRNA}

This was performed according to the protocol, using the Affymetrix Enzo BioArray High Yield RNA Transcript Labelling Kit. $20 \mu \mathrm{g}$ of this labelled and purified cRNA was then fragmented (according to the protocol) prior to the hybridization step.

\section{Hybridization}

The hybridization cocktail was prepared according to the Affymetrix instructions, and incubated with the array at $45{ }^{\circ} \mathrm{C}$ for $16 \mathrm{~h}$ in rotisserie oven at 60 r.p.m.

\section{Washing, staining and scanning}

Washing and staining was performed in the Affymetrix Fluidics Station 400 according to the standard format of the single stain protocol for eukaryotic targets.

\section{Data analysis}

Data from the chip hybridizations was processed using GeneSpring 6 software (Silicon Genetics, Redwood City, CA, USA). Human U133 A microarray chips were hybridized with biotin-labelled cRNA from the following myometrial cell lines: (i) control non-transfected primary cultures (Ctrl), two replicates; (ii) control cells stably transfected with empty vector with no insert downstream of a cytomegalovirus (GMV) promoter $(\mathrm{CMV}-)$, three replicates; (iii) cells stably transfected with a plasmid to express CREB (GREB), three replicates; (iv) cells stably transfected with a plasmid to express CREM $\tau_{2} \alpha$ $\left(\mathrm{CREM} \tau_{2} \alpha\right)$, three replicates; (v) cells stably transfected with a plasmid to express CREM $\alpha$ (CREM $\alpha$ ), three replicates. Raw-data files direct from the Affymetrix chip scanner were imported into the GeneSpring program for each chip. These data sets were transformed by converting all signal values below 0.01 to $0 \cdot 01$, then subjected to per-chip normalization to the 50th percentile and per-gene normalization to the median. To determine a baseline profile of gene expression with which to compare the CREB, GREM $\tau_{2} \alpha$ and CREM $\alpha$ results, an initial comparison was made between the control cell lines (i) and (ii), using normalized data from the primary non-transfected cells (i) as an initial baseline and data from the CMV - empty vector-transfected cells (ii) as the experimental set. This established which genes were affected by the stable transfection of the vector and subsequent selection process, and which therefore should be excluded from the main analyses involving the CREB/CREM constructs. According to related literature (Mayanil et al. 2001, Gibellini et al. 2002), an appropriate cut-off point for this purpose is in the region of greater than or equal to a 1.5-2-fold change in expression; a 1.5-fold cut-off was used in our analysis. This was achieved by performing a parametric one-way ANOVA on the normalized data assuming equal variances, incorporating the Benjamini and Hochberg False Discovery Rate multiple-testing correction set at a rate of $0 \cdot 05$. The resultant list of genes differentially expressed between the two control classes was then filtered to include only those genes showing a fold change in expression of 1.5 or greater. These genes were then subtracted from the list of genes represented on the Affymetrix Human 133 A chip (22 283), resulting in the elimination of genes whose expression was altered by the process of stable transfection and selection. The remaining data set following this exclusion was then used as a final baseline for comparisons with CREB/CREM expression. These comparisons involved much the same process; data was normalized as above, then compared with gene expression levels in the 'final baseline' by ANOVA using the same criteria. The results were then filtered to include only those genes whose expression altered by a fold change of 2 or greater. Often, results from microarray experiments are also filtered using the criteria of their Absolute and Difference calls; only Absolute calls of Present and Difference calls of Increased or Decreased are included. However, certain reports in which there were a number of known genes that were expected to show altered expression under experimental conditions have suggested that this methodology results in the erroneous rejection of truepositive results. Consequently, Absolute calls were not used as a basis for exclusion in our analyses.

\section{SQ RT-PCR}

In order to support the results obtained from the microarray experiments, a selection of candidate genes were examined for differential expression as a result of the over-expression of CREB, CREM $\tau_{2} \alpha$ and CREM $\alpha$ by SQ RT-PCR. The primers used for this were as follows, where $\mathrm{F}$ is forward primer and $\mathrm{R}$ is reverse primer. All sequences are shown $5^{\prime}$ to $3^{\prime}$. glyceraldehyde-3-phosphate dehydrogenase (GAPDH), F, CTGGCGTCTAGAAAAACG; R, GCACGTTCG TTGTCATACG; matrix metalloproteinase 1 (MMP1), F， GCTCGGTGGGAGCAAACAC; R, AAGGCTT TGTCAATGGGATGGTC; PTPRB, F, TGGGCTAC CTTTGGGATAGACA; R, GGAGGAGGTAAAGGA TCTGTTTG; PRKGA, F, CGTTTGGAGTTTCGG AGGTGA; R, AGTTCGATGTTTCGTTGGTCGTC; PLA2R1，F，CAGGTGGTGGAGACATTTGTG; R, GGTGGGTGTTCGGTTTGATT; CRSP8, F, TGGA GGACAACTTACATTCGGTC; R，TCTCAGATG 
GGTTGCGTACGA; SMARGAL1，F，TGGGGAAC TCATTGAAGTGTT; R, TGAAGTTCAAGGTCT TGGTGTC; GDKN1C， F， GAGAAGTCGTCGG GCGATG; R, GGCTCTTTGGGCTCTAAATTGG; GPR30，F， CAACATCTGGAGGGCAGGTAC; R, CTCGTCACACGGGGATGGT; CDC42EP2, F, ACGCTCCTCAGCGCTGGAC; R, GCAAGAAAGG TAGGAACTGTGTG; FMOD, F, CAAGGCAATAG GATCAATGAGTTC; R, CTTGATCTCGTTCCG GTCGA; HUMNK1A, F, ACGGCTACGACGAGCA AGTC; R, TGCACACGACGACAATCATCA; SUI1, F, CGGAGGATTCAGCAGCGT; R, AAAACCGAT GAACCTTCAGC; MTCO1, F, TTGGCGGACA GTTGACTATT; R, TAGGGGTTCTTCGAATGT GTG; Palladin, F, GCGAGGTATAAAGCCGGA; R, GGTTAGATCTGGGGTTGGTAA; CTGF, F, CAAGGGGCTCTTCTGTGACTT; R, TGCGTCGT CTTTGCAAACAA; CDKN1A， F， AGCTGCCG AAGTCAGTTCGT; R, AACTAGGGTGGCGTTCT TCTT; gp(96)1, F, TGGAGGTGTGAGGATCGGAA; R, GCAAGACGTGTTCGATTGGA; COL4A1, F, ACGGTGGGTATCGGTGGAA; R，TGCGCTGGG AAAGGTATTTCT; LIM, F, GAGTGAGTTGTCAG CACTTGT; R, ACATTGTTCGGAATGGGGTT.

SQ RT-PGR was performed using the SuperScript OneStep RT-PCR system. $50 \mathrm{ng}$ DNase-treated total RNA from stably transfected cells, or $5 \mathrm{ng}$ mRNA from pooled $(n=6) \mathrm{NP}$ or $\mathrm{P}$ myometrial tissue was used as template according to the manufacturer's protocol, and a total of 28, 30 and 32 cycles of PCR performed at an appropriate annealing temperature for each particular primer pair to ascertain the best quantitative signal for each target sequence following agarose gel electrophoresis (2\% E-gels; Invitrogen) of the products. Image analysis and band intensities were analysed with the Intelligent Quantifier program (Bio Image Systems, Jackson, MI, USA).

\section{Real-time RT-PCR analysis}

Forward primers were designed using LUX primerdesign software (www.invitrogen.com) and were as follows: CREB PRKCA, 5'-GAGGAGAGTTCGAT GTTTCGTTCGTCGG-3' and CREM $\alpha$ CDKN1C, 5'-CATCGGAGAAGTCGTCGGGGGAG- 3'. Reverse non-LUX-labelled primers were as above for SQ RTPCR. Reactions were performed using the SuperScript III Platinum One-Step Quantitative RT-PGR System (Invitrogen). Reactions were set-up in $25 \mu \mathrm{l}$ volumes according to the manufacturer's protocol, and cycled as follows: $50{ }^{\circ} \mathrm{C}$ for $15 \mathrm{~min}, 95^{\circ} \mathrm{C}$ for $2 \mathrm{~min}$, then 45 cycles of $95{ }^{\circ} \mathrm{C}$ for $15 \mathrm{~s}$ and $60{ }^{\circ} \mathrm{C}$ for $30 \mathrm{~s}$. Commercially available LUX primers (Invitrogen) were used to amplify GAPDH as a reference gene. Melting-curve analysis was performed to ensure reaction specificity, and relative quantitation was determined by standard curve analysis.

\section{Results}

\section{Stable transfection and microarray data}

Following the stable-transfection and selection process, cell lines were examined to verify that (i) they were predominantly composed of myometrial smooth muscle cells and that fibroblast contamination had been successfully kept to a minimum, and (ii) the cells had not been damaged in any way, i.e. were in a healthy state with no gross morphological changes. Fig. 2a and b show the results of these examinations following the appropriate cell-staining procedures, indicating not only a low-level presence of fibroblasts in the cultures, but also a normal morphology in the stably transfected cell lines when compared with the non-transfected control. The degree of fibroblast contamination was estimated by microscopic cell counting of slide-mounted and stained cultures, and was consistently less than $1 \%$. This was achieved via the use of $\mathrm{D}$-valine (substituting L-valine) growth medium, which has long been known to inhibit the growth of fibroblasts (Gilbert \& Migeon 1975, 1977, White et al. 1978, Frauli \& Ludwig 1987, Sordillo et al. 1988, Hongpaisan 2000).

Agarose gel electrophoresis of CREB and CREM RT-PCR products from stably transfected cell lines revealed a wide range of expression levels between isolated clones (Fig. 2c). Total RNA was isolated and purified from those colonies showing the highest levels of expression, and amplified and labelled prior to microarray hybridization and analysis according to the methods described below. The microarray data derived from Chip Sequence files for all hybridizations including the cell-only control, two replicates of the empty-vector control and three replicates of each of the CREB, CREM $\tau_{2} \alpha$ and CREM $\alpha$ experimental samples, have been submitted to the NCBI gene expression and hybridization array data repository GEO (http:// www.ncbi.nlm.nih.gov/geo/), under GEO numbers GSM 17039, GSM 17040, GSM 17041, GSM 17042, GSM 17059, GSM 17060, GSM 17061, GSM 17062, GSM 17063, GSM 17064, GSM 17065 and GSM 17066. Following hybridization and scanning, chip data were imported into the GeneSpring software for normalization and manipulation. Rather than simply comparing gene expression between the stably transfected cell lines and the control empty-vector cell line directly, we derived a 'final baseline' of gene expression in cultured myometrial cells with which to compare the experimental data from the stably transfected cells, as detailed in the Materials and methods section, which takes into account expression differences induced by the transfection and selection processes. Although this may increase the incidence of false negatives in the form of genes genuinely altered by the expression of the transfected factors and not by transfection and selection, it drastically reduces the incidence of false positives, i.e. 
(a)

(i)

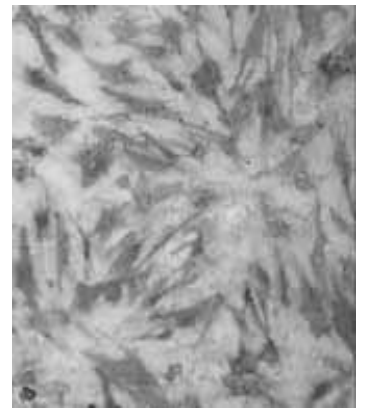

(iii)

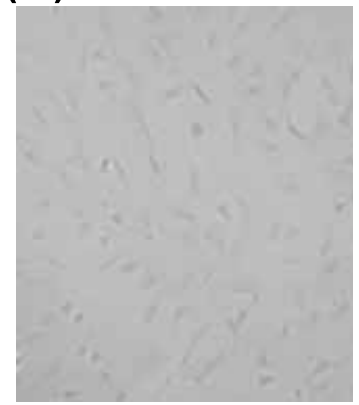

(ii)

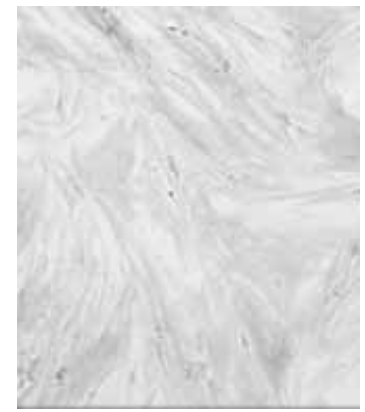

(iv)

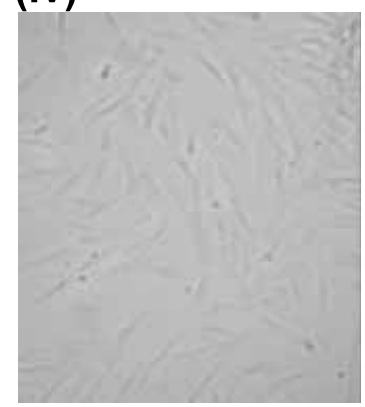

(b)

(i)

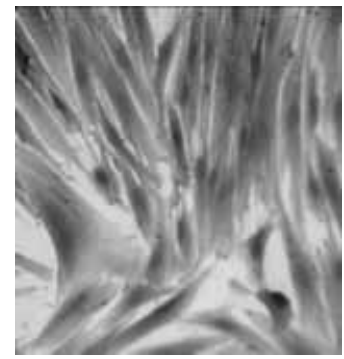

(iii)

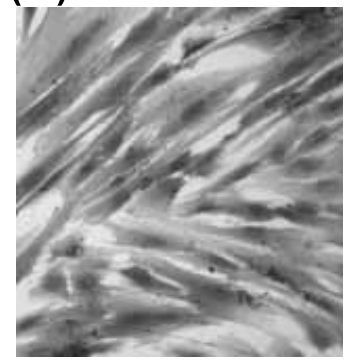

(ii)

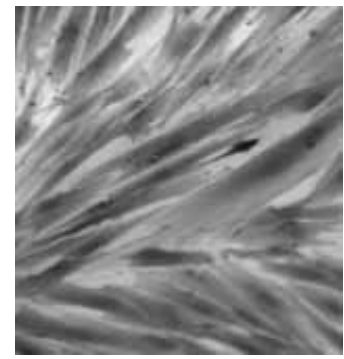

(iv)

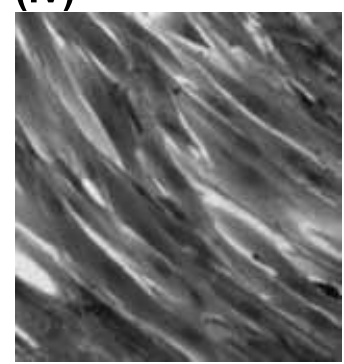

(v)

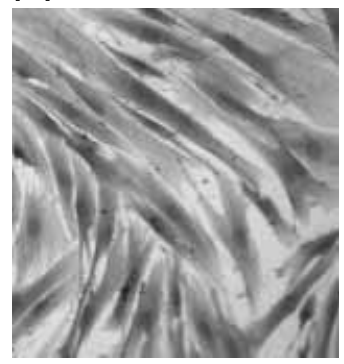

(c)
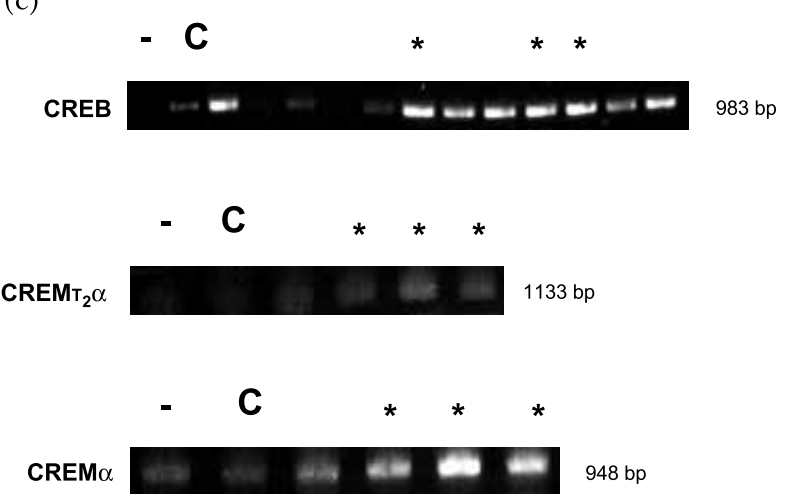

Figure 2 (a) Immunocytostaining of human myometrial and fibroblast cultured cells using anti-fibroblast specific antigen (Ab-1) mAb ASO2 (Oncogene Research Products). (i) Note intense anti-ASO2 reactivity with fibroblast cells, in contrast to the light staining with myometrial cells in (ii). Negative controls, omitting the primary ASO2 mAb, are shown in (iii) and (iv) for fibroblast and myometrial cells respectively. (b) Haematoxylin and eosin staining of stably transfected myometrial cells expressing (i) CREB, (ii) CREM $\alpha$ and (iii) $\mathrm{CREM} \tau_{2} \alpha$. Morphology was compared with control non-transfected (iv) and empty-vector stably transfected (v) cells, and showed no differences. (c) RT-PCR analysis of isolated stably transfected colonies to determine abundance of CREB, CREM $\alpha$ and $\mathrm{CREM} \tau_{2} \alpha$ mRNAs. Total RNA was isolated from these cell lines, and used as a template for RT-PCR of these CREB/CREM isoforms. Expression levels were compared with control non-transfected (-) and empty-vector stably transfected (C) cells. Those with the highest degrees of expression $\left(^{*}\right)$ were used as the three replicate RNA populations for the microarray analysis. 
Table 1 Number of genes affected by stable expression of CREB, CREM $\alpha$ and CREM $\tau_{2} \alpha$ in cultured myometrial cells according to data from Affymetrix Human 133 A microarray chips and GeneSpring data mining. Normalized gene-expression levels for stable cell lines transfected with expression constructs for the CREB, CREM $\alpha$ and CREM $\tau_{2} \alpha$ genes were compared to normalized baseline levels as described in the Material and methods section. Out of a possible 20966 genes, the number of genes whose expression was altered by 1.5 -fold or greater is shown, along with the number of genes up- and down-regulated

\begin{tabular}{|c|c|c|c|c|}
\hline & \multirow{2}{*}{$\begin{array}{l}\text { No. of } \\
\text { downstream } \\
\text { genes affected }\end{array}$} & \multirow{2}{*}{$\begin{array}{l}\text { Affected genes } \\
\text { per chip (\%) }\end{array}$} & \multicolumn{2}{|l|}{ No. of genes } \\
\hline & & & Up-regulated & Down-regulated \\
\hline \multicolumn{5}{|c|}{$\begin{array}{l}\text { Stably- transfected } \\
\text { gene }\end{array}$} \\
\hline CREB & 958 & 4.57 & 522 & 436 \\
\hline CREM $\alpha$ & 118 & 0.56 & 71 & 47 \\
\hline $\mathrm{CREM} \tau_{2} \alpha$ & 220 & 1.05 & 148 & 72 \\
\hline
\end{tabular}

genes affected by transfection and selection and not by the transfected factors themselves. This process indicated that the expression of a total of 1317 genes $5.9 \%$ of the total) was affected significantly (greater than or equal to $1 \cdot 5$-fold) by the transfection and selection process, of which 879 were up-regulated and 438 down-regulated. This total does not seem excessive: similar studies have shown $16 \%$ of genes to be affected in this way (Mayanil et al. 2001). These genes were subtracted from the 22283 represented on the microarray chip, to give a final baseline of 20966 genes. All subsequent analyses of gene expression in the stably transfected cell lines included data for these genes only, and the mean levels of expression in this final baseline were used as the basis for these comparisons, the outcome of which is summarized in Table 1, which presents the numbers of genes up- and down-regulated by the three bZIP factors under investigation. Due to the comprehensive nature of this study utilizing microarrays on which over 20000 genes are represented, the volume of information in our results was substantial. Consequently, these results have been split into categories for presentation: Fig. 3a lists those genes affected by the three bZIP factors that are directly attributable to uterine function on the basis of current knowledge. The remainder of affected genes are listed in online supplementary Fig. 3b-d (see http:// jme.endocrinology-journals.org/content/vol34/issue1/) for CREB, CREM $\alpha$ and CREM $\tau_{2} \alpha$ respectively, plus an additional figure (online Supplementary Fig. 3e) containing those genes affected by CREB that are classified only as clones, hypothetical proteins, expressed sequence tags (ESTs) and open reading frames $(\mathrm{ORFs})$, and also annotated genes that have not, as yet, been linked to significant myometrial activity.

The expression of a number of the genes determined by microarrays was altered by more than one of these three bZIP factors, as summarized in Fig. 4. From a total of 1296 genes found to be significantly altered as a result of CREB, GREM $\alpha$ or CREM $\tau_{2} \alpha$ expression, 112 were regulated by more than one of these three factors. Of these 112, eight were affected by all three, 31 were affected by CREB and CREM $\alpha, 65$ were affected by CREB and CREM $\tau_{2} \alpha$, and eight were affected by CREM $\alpha$ and CREM $\tau_{2} \alpha$. The genes in these lists were classified and grouped according to their functions as determined by the GeneSpring software; where genes belonged to more than one functional group, the results tables were edited manually to prevent multiple entries of these particular genes.

\section{Genes affected by CREB, CREM $\alpha$ or CREM $\tau_{2} \alpha$ expression, classified according to GeneSpring}

The results revealed a diverse range of gene categories in terms of biological processes, cellular components and molecular functions that are regulated by these bZIP factors. The most pertinent genes and groups of genes known to be involved in the function of the human uterus were selected from our results and are presented in Fig. 3a. Due to the number of genes included, their functions, properties and links to human uterine activities cannot be elaborated upon in detail here: however, for each gene or group of genes, Fig. 3a contains appropriate comments or citations to relevant publications that support their inclusion. In addition to these genes, other examples include those responsive to oestrogen, cAMP and calcium; splicing factors and genes involved in their control, hormone receptors, A-kinase anchoring proteins (AKAPs), transcription factors, zincfinger and LIM-domain proteins, ion channels, cytoskeletal proteins, adhesion molecules, extracellular components, histones and histone-modification genes, kinases, GPGRs, chemokines and chemokine receptors and proteoglycans. Full listings of results further to those in Fig. 3a can be found in online Supplementary Fig. 3b-e.

\section{SQ and real-time RT-PCR}

The validity of the microarray results was examined by performing a panel of SQ/real-time RT-PGR reactions. 
(a) Gene(s) $\quad \uparrow / \downarrow \quad$ References/comments

Cell surface linked signal transduction

\begin{tabular}{|c|c|c|}
\hline Integrins $\alpha 4, \beta 2, \beta 4, \beta 8$ & $\uparrow$ & Taylor et al. 1996; Terpe et al. 1994 \\
\hline Voltage-dependent $\mathrm{Na}^{+} \& \mathrm{~K}^{+}$channels & $\downarrow$ & $\begin{array}{l}\text { Sanborn 2000b; Sperelakis et al. 1992; Toro } \\
\text { et al. } 1990\end{array}$ \\
\hline
\end{tabular}

Cytokines, hormones \& receptors

Interleukins (IL8 \& 18) \& IL-receptor 17C

Chemokine ( $\mathrm{C}-\mathrm{C}$ motif) ligands

Keelan et al. 2003; Tribe et al. 2003; Osman et al. 2003; Bowen et al. 2002; Chan et al.

$\uparrow \downarrow$ 2002; Helmer et al. 2002; Friebe-Hoffman et al. 2001; Rauk et al. 2001; Schmid et al. 2001; Elliot et al. 2000; Hatthachote \& Gillespie 1999

Al-Matubsi et al. 2001; Ou et al. 2000;

Prostaglandin F, LH/hCG, \& oxytocin receptors

$\uparrow \quad$ Sparey et al. 1999; Zuo et al. 1994; Moonen et al. 1986; Fuchs et al. 1984

\section{Cytoskeletal proteins}

\begin{tabular}{ll}
\hline Supervillin & $\begin{array}{l}\text { Chen et al. 2003 } \\
\text { CBP/p300-interacting transactivator }\end{array}$ \\
Tropomyosin $1 \alpha$ & $\begin{array}{l}\text { AP2 co-activator } \\
\text { Component of actin filaments of myofibrils }\end{array}$
\end{tabular}

\section{Extracellular matrix}

$\begin{array}{ll}\text { Collagen (types XIII } \alpha 1, \mathrm{XI} \alpha 2, \mathrm{~V} \alpha 1, \mathrm{VI} \alpha 2, \mathrm{XVI} & \text { Weston et al. 2003; Dziadek et al. 1995; } \\ \alpha 1, \mathrm{IV} \alpha 2, \mathrm{VI} \alpha 1, \mathrm{IV} \alpha 3, \mathrm{XVIII} \alpha 1) & \text { Goranova et al. 1993; Nishinaka \& Fukuda } \\ & 1991 \\ \text { Matrix metalloproteinases (MMPs) } 1 \text { \& 23A } & \uparrow \quad \text { Ma \& Chegini 1999; Dumin et al. } 1998\end{array}$

Intracellular signalling

Voltage gated $\mathrm{Na}^{+} / \mathrm{K}^{+}$channel peptides $\uparrow$

Rho GTPase activating proteins $1 \& 6 \quad \downarrow$ Prakash et al. 2000

Protein kinases

Protein kinase $C$ isoforms $\alpha, \beta 1 \& \zeta \quad \uparrow \quad$ Eude et al. 2000; Morrison et al. 1996

Transport

Genes involved in transport of $\mathrm{K}^{+}, \mathrm{Ca}^{2+}, \mathrm{Na}^{+}, \mathrm{Zn}^{2+}$ \& glucose-6-phosphate

Esplin et al. 2003; Curley et al. 2002;

$\uparrow / \downarrow$ Sanborn 2000b; Murugesan et al. 1989; Honore et al. 1986; Kelly \& Abel 1983

Figure 3 (a).

11 randomly selected genes were chosen from the results of the CREB, GREM $\alpha$ and CREM $\tau_{2} \alpha$ microarray experiments, and, by SQ RT-PCR, their mRNA levels assessed in control cultured myometrial cells transfected with empty vector, the stably transfected myometrial cell line used for the array hybridization, pooled NP tissue and pooled $\mathrm{P}$ tissue (Fig. 5). In each case, the level of expression in stably transfected cells compared with control cells reflected the results from the microarrays: those genes found to be up- or down-regulated by 
(b)

\section{Pregnancy}

Pregnancy-specific glycoproteins $3,6 \& 9$

$\uparrow \quad$ Snyder et al. 2001

\section{Non-classified/other}

Calpain-10

Transient receptor potential channels (Trp) C4 \& C5

MEF2D (component of smooth-muscle specific complex)

CALCRL (calcitonin receptor-like gene)

Smag-64 (smooth-muscle activation-specific gene)

Corticotropin releasing hormone receptors $\mathrm{CRH}$ $\mathrm{R} 1$ \& $\mathrm{CRH}-\mathrm{R} 2$

Suppressor of cytokine signalling SOCS1

$\alpha 2$-adrenoceptors $\alpha 1 \mathrm{~A}-\mathrm{AR} \& \alpha 2 \mathrm{~A}$

$\beta 2$-adrenoceptor $\beta 2$-AR

Prostaglandin receptors D2 (DP) \& EP3 $\uparrow \quad$ Belt et al. 1999

$\uparrow / \downarrow$ Dalrymple et al. 2002

$\uparrow \quad$ Katoh et al. 1998

$\downarrow \quad$ Dong et al. 1999

$\uparrow$ Preferentially expressed in neointimal smooth muscle cells

$\uparrow / \downarrow$ Grammatopoulos \& Hillhouse 1999

$\uparrow \quad$ Blumenstein et al. 2002

$\uparrow / \downarrow$ Involved in myometrial contraction

$\uparrow$ Increase cAMP: myometrial relaxation

$\downarrow$ Keelan et al. 2003

Figure 3 (b).

Figure 3 (a) Total RNA samples were isolated from stably transfected cell lines expressing CREB, $\mathrm{CREM} \alpha$ and $\mathrm{CREM} \tau_{2} \alpha$. Human U133 A array chips were hybridized with biotin-labelled cRNA representing the mRNA populations of cultured myometrial cells in the form of (i) non-transfected controls, (ii) empty-vector stably transfected controls and (iii) stably transfected experimental lines over-expressing the CREB, CREM $\tau_{2} \alpha$ or CREM $\alpha$ bZIP transcription factors. Details are given in the Data analysis and first Results sections. Due to the comprehensive number of genes involved, the resultant lists are published as online supplementary Fig. 3b-e (see http://jme.endocrinologyjournals.org/content/vol34/issue1). The most germane of these are listed here, comprising genes from several functional groups. All are attributable to the control of uterine/myometrial function, and references as such are included in the figure to minimize the length of elaboration in this report. In each case, the effect of CREB/CREM on the expression of the gene/genes is indicated by arrows, where $\uparrow$, up-regulation, $\downarrow$, down-regulation, and $\uparrow / \downarrow$, both up- and down-regulation for groups of genes, or where a specific gene was affected differently by more than one of the bZIP factors.

expression of the CREB and CREM factors by microarray analysis also showed increased or decreased expression respectively in the stable cell lines compared with control cells by RT-PCR. In addition, the expression of these genes was found to be significantly altered between the pooled NP and P tissue, reflecting the in vivo biological situation. Of the 11 genes examined, six were expressed to a greater degree in NP tissue compared with $\mathrm{P}$ tissue, four were expressed at a higher level in $\mathrm{P}$ tissue in comparison to NP tissue, and one gene showed no significant difference in expression levels. Real-time RT-PCR analysis of two of these genes, PRKCA and CDKN1C, indicated significant up- and down-regulation respectively of their expression in stable cell lines in accordance with the microarray data, and also increased expression in NP tissue compared with $\mathrm{P}$ tissue reflecting the in vivo situation.

\section{Discussion}

We have previously identified and described a cAMPresponsive genetic component in the human myometrium during pregnancy, in the form of the temporal and spatial expression of a number of specific splice variants of ubiquitous bZIP transcription factors. In an attempt to discover the downstream genes affected by these factors, we examined gene expression in myometrial cell lines stably transfected with expression constructs of CREB, CREM $\alpha$ and CREM $\tau_{2} \alpha$, and compared it to control cells, by way of isolation of RNA from these cells and hybridization of biotin-labelled cRNA copies to Affymetrix human microarray chips.

After confirming that our cell cultures comprised less than $1 \%$ contaminating fibroblasts, we derived a baseline of expression with which to compare the expression 
(a)
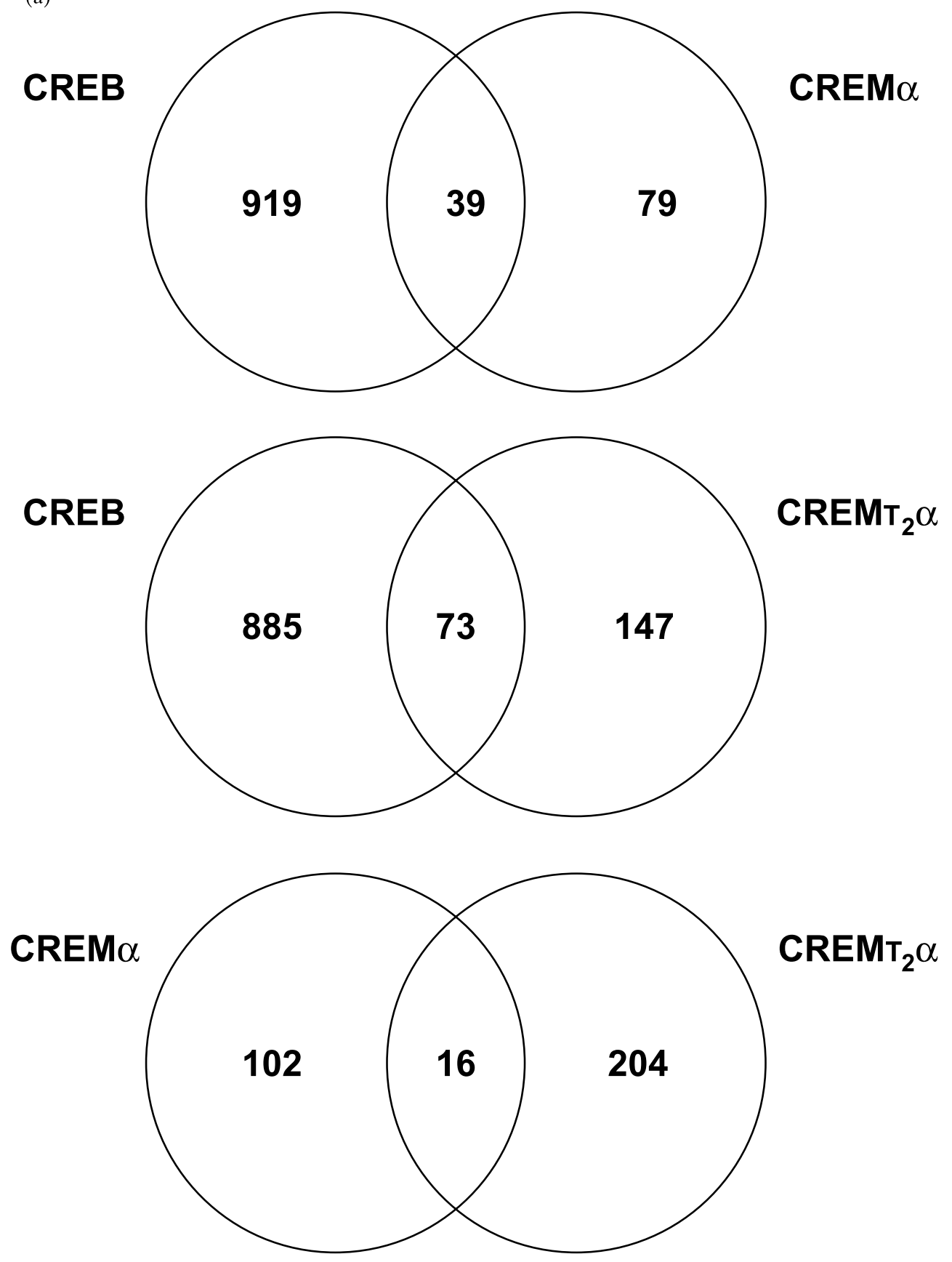

Figure 4 (a).

profile of the stably transfected bZIP cell lines. This was achieved by comparing gene expression in control cells stably transfected with empty vector against control non-transfected cells. Although a relatively uncommon approach (most studies simply compare experimental expression cell lines with empty-vector controls), we believe that accounting for changes in gene expression due to the biochemically stressful transfection and selection processes is essential to obtain more-robust results. While this essentially produces a number of false negatives in the form of genes genuinely altered by the expression of the transfected factors and not by transfection and selection, it drastically reduces the incidence of false positives, i.e. genes affected by transfection and 
(b)

\begin{tabular}{|c|c|c|c|c|c|}
\hline \multirow{2}{*}{\multicolumn{6}{|c|}{ Genes affected by CREB, CREM $\alpha \&$ CREMT $_{2}{ }^{\text {Genen }}$}} \\
\hline & & & & & \\
\hline \multirow[t]{2}{*}{ SMARCAL1 } & $\begin{array}{l}\text { SWI/SNF related, matrix associated, actin dependent } \\
\text { regulator of chromatin subfamily a-like } 1\end{array}$ & NM_014140 & $5.3 \uparrow$ & $5.2 \uparrow$ & 7.61 \\
\hline & $\begin{array}{l}\text { ESTs, Highly similar to uncharacterized hypothalamus } \\
\text { protein } \mathrm{HTT} 10 \text { [Homo sapiens][H sapiens] }\end{array}$ & S AF119892.1 & $4.1 \uparrow$ & $4.3 \uparrow$ & $5.6 \uparrow$ \\
\hline \multirow{2}{*}{$\begin{array}{l}\text { HIST1H2BI } \\
\text { KCNH2 }\end{array}$} & $\mathrm{H} 2 \mathrm{~B}$ histone family, member K & NM_003525 & $3.6 \uparrow$ & $4.7 \uparrow$ & $5.3 \uparrow$ \\
\hline & $\begin{array}{l}\text { potassium voltage-gated channel, subfamily } \mathrm{H} \text { (eag- } \\
\text { related), member } 2\end{array}$ & AB044806.1 & $2.5 \downarrow$ & $2.8 \downarrow$ & $2.8 \mathrm{t}$ \\
\hline & AL576654 & $3.2 \downarrow$ & $2.8 \downarrow$ & $3.3 \downarrow$ \\
\hline \multicolumn{2}{|c|}{$\begin{array}{l}\text { E46L; } \\
\text { DKFZ2 fibulin } 1 \\
19\end{array}$} & Z95331 & $9.1 \downarrow$ & $3.1 \downarrow$ & $9.0 \mathrm{t}$ \\
\hline & hypothetical protein MGC108 & NM_030569 & $25.0 \downarrow$ & $33.3 \downarrow$ & $34.4 \downarrow$ \\
\hline \multirow{2}{*}{ GAS1 } & growth arrest-specific 1 & AW611727 & $33.3 \downarrow$ & $33.3 \downarrow$ & $51.1 \downarrow$ \\
\hline & Gene & Genbank & CREB & CREM $\alpha$ & \\
\hline \multicolumn{6}{|c|}{ Genes affected by CREB \& CREM $\alpha$} \\
\hline \multirow{2}{*}{$\begin{array}{l}\text { PTENP1 } \\
\text { D21S2056E }\end{array}$} & $\begin{array}{l}\text { phosphatase and tensin homolog (mutated in multiple } \\
\text { advanced cancers 1), pseudogene } 1\end{array}$ & AF023139.1 & $9.3 \uparrow$ & $11.8 \uparrow$ & \\
\hline & $\begin{array}{l}\text { DNA segment on chromosome } 21 \text { (unique) } 2056 \\
\text { expressed seguence }\end{array}$ & NM_003683 & $8.1 \uparrow$ & $8.1 \uparrow$ & - \\
\hline \multirow{2}{*}{$\begin{array}{l}\text { SNRK } \\
\text { FANCF }\end{array}$} & SNF-1 related kinase & NM_017719 & $7.3 \uparrow$ & $5.1 \uparrow$ & \\
\hline & Fanconi anemia, complementation group $\mathrm{F}$ & NM_022725 & $5.8 \uparrow$ & $7.8 \uparrow$ & - \\
\hline \multirow{2}{*}{$\begin{array}{l}\text { TFAM } \\
\text { GDF2 }\end{array}$} & transcription factor $\mathrm{A}, \mathrm{mi}$ & NM_012251 & $5.1 \uparrow$ & $10.4 \uparrow$ & - \\
\hline & growth differentiation factor 2 & NM_016204 & $4.9 \uparrow$ & $3.7 \uparrow$ & . \\
\hline \multirow{2}{*}{$\begin{array}{l}\text { POMT2 } \\
\text { ITGB8 }\end{array}$} & putative protein O-mannosyltransferase & NM_013382 & $4.9 \uparrow$ & $6.3 \uparrow$ & 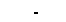 \\
\hline & integrin, & NM_002214 & $4.5 \uparrow$ & $2.8 \uparrow$ & - \\
\hline \multirow{2}{*}{$\begin{array}{l}\text { EVA1 } \\
\text { CFLAR }\end{array}$} & epithelial V-like antigen 1 & AF275945.1 & $4.0 \uparrow$ & $2.7 \uparrow$ & \\
\hline & CASP8 and FADD-like apoptosis regulator & AF005775.1 & $3.3 \uparrow$ & $3.2 \uparrow$ & . \\
\hline \multirow[t]{4}{*}{ EMP1 } & epithelial membrane protein 1 & NM_001423 & $3.9 \uparrow$ & $4.7 \uparrow$ & \\
\hline & $\begin{array}{l}\text { Homo sapiens mRNA; cDNA DKFZp434P2435 (from } \\
\text { clone DKFZp434P2435), mRNA sequence }\end{array}$ & AL 117520.1 & $3.9 \uparrow$ & $4.0 \uparrow$ & - \\
\hline & $\begin{array}{l}\text { Homo sapiens cDNA: FLJ22209 fis, clone HRC01496, } \\
\text { mRNA sequence }\end{array}$ & AK025862.1 & $3.3 \uparrow$ & $2.8 \uparrow$ & - \\
\hline & $\begin{array}{l}\text { Homo sapiens CDNA FLJ13754 fis, clone } \\
\text { PLACE } 3000362 \text {, mRNA sequence }\end{array}$ & AK023816.1 & $2.8 \uparrow$ & $2.4 \uparrow$ & - \\
\hline \multirow{2}{*}{$\begin{array}{l}\text { SOCS1 } \\
\text { MGC2508 }\end{array}$} & suppressor of cytokine signaling 1 & AB005043.1 & $2.2 \uparrow$ & $3.6 \uparrow$ & - \\
\hline & hypothetical protein MGC2508 & AA639585 & $2.7 \uparrow$ & $2.9 \uparrow$ & - \\
\hline \multirow[t]{2}{*}{ SMT3H2 } & SMT3 $\mathrm{s}$ & Al971724 & $2.5 \uparrow$ & $3.0 \uparrow$ & 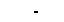 \\
\hline & $\begin{array}{l}\text { Homo sapiens cDNA: FLJ21533 fis, clone COL06072, } \\
\text { mRNA sequence }\end{array}$ & BE965029 & $2.4 \uparrow$ & $2.1 \uparrow$ & - \\
\hline YKT6 & SNARE & NM_00 & $2.2 \uparrow$ & $\uparrow$ & - \\
\hline PSG3 & pregnancy specific beta-1-glycoprotein 3 & AB019570.1 & $3.0 \uparrow$ & $2.5 \uparrow$ & - \\
\hline FLJ10661 & hypothetical protein FLJ10661 & NM_018172 & $2.1 \dagger$ & $2.5 \uparrow$ & . \\
\hline SPHK2 & sphing & AF245447.1 & $2.4 \downarrow$ & $2.7 \downarrow$ & \\
\hline WBSCR5 & Williams-Beuren syndrome chromosome region 5 & AF257135.1 & $2.4 \downarrow$ & $3.8 \downarrow$ & . \\
\hline & & BE892698 & $3.1 \downarrow$ & $8.7 \downarrow$ & - \\
\hline $\mathrm{AAO3}-3$ & KIAA03 & AB002361.1 & $3.7 \downarrow$ & $3.1 \downarrow$ & . \\
\hline SEMA3B & $\begin{array}{l}\text { sema domain, immunoglobulin domain (lg), short basic } \\
\text { domain, secreted, (semaphorin) } 3 B\end{array}$ & c NM_004636 & $2.2 \downarrow$ & $3.1 \downarrow$ & - \\
\hline BRDG1 & BCR do & $\mathrm{N}$ & & 59 & - \\
\hline GRTP1 & hypothetical protein FLJ22474 & NM_024719 & $5.6 \downarrow$ & $2.3 \downarrow$ & - \\
\hline PACE4 & paired basic amino acid cleaving system 4 & D28514.1 & $7.7 \downarrow$ & $7.1 \downarrow$ & - \\
\hline IL26 & interleu & NM_018402 & $8.3 \downarrow$ & $9.1 \downarrow$ & - \\
\hline KIAA0987 & erythrocyte membrane protein band 4.1 -like 3 & NM_012307 & $14.3 \downarrow$ & $11.7 \downarrow$ & - \\
\hline & Gene & Genbank & CREB & CREM $\alpha$ & \\
\hline enes aff & fected by CREB \& CREMT $2 \alpha$ & & & & \\
\hline & Homo sapiens clone IMAGE:248602, mRNA sequence & e AF339805.1 & $66.2 \uparrow$ & - & $49.1 \uparrow$ \\
\hline FLJ 20060 & FLJ 20060 & NM_017645 & $39.7 \uparrow$ & - & $31.0 \uparrow$ \\
\hline GAL & decarboxylase 2 (pancr & ר. M81882.1 & $3.3+$ & & $5.0 \uparrow$ \\
\hline CYP2C8 & $\begin{array}{l}\text { cytochrome P450, subfamily IIC (mephenytoin 4- } \\
\text { hydroxylase) polypeptide } 8\end{array}$ & NM_030878 & $7.7 \downarrow$ & - & $7.1 \uparrow$ \\
\hline & hypothetical protein & AW576871 & $8.2 \uparrow$ & - & $7.2 \uparrow$ \\
\hline & $\begin{array}{l}\text { Homo sapiens cDNA clone IMAGE: } 39437345^{\prime} \text {, MRNA } \\
\text { sequence }\end{array}$ & BE794962 & $5.7 \uparrow$ & - & $5.9 \dagger$ \\
\hline & bosomal RNA gene, complet & M111 & 3 & - & $15.7 \dagger$ \\
\hline CDK5R1 & cyclin-dependent kinase 5 , regulatory subunit 1 ( $p 35)$ & AL567411 & $5.3 \uparrow$ & - & $5.4 \uparrow$ \\
\hline COIL & coilin & BG391060 & $5.1 \uparrow$ & - & $3.9 \dagger$ \\
\hline FGF18 & fibrobla & AB007422.1 & $5.0 \uparrow$ & - & $5.4 \uparrow$ \\
\hline $\mathrm{C} 1 \mathrm{QB}$ & it component 1 , q su & NM_000491 & $4.9 \uparrow$ & - & $4.8 \mathrm{\dagger}$ \\
\hline & & $\mathrm{M} 2 \mathrm{~T}$ & & - & 9.2 \\
\hline SRT & c response-7 proteir & NM 018559 & $4.6 \uparrow$ & - & $3.3 \uparrow$ \\
\hline L1 & & M5921 & $4.0 \uparrow$ & - & 7. \\
\hline & owth factor 1 & NM_003867 & $4.2 \uparrow$ & 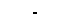 & $7.6 \uparrow$ \\
\hline
\end{tabular}

\begin{tabular}{|c|c|c|c|c|c|}
\hline \multirow{2}{*}{\multicolumn{2}{|c|}{$\begin{array}{l}\text { Gene } \\
\text { Genes affected by CREB \& CREMT }{ }_{2} \alpha \text { contd }\end{array}$}} & \multirow[t]{2}{*}{ Genbank } & \multirow[t]{2}{*}{ CREB } & \multirow[t]{2}{*}{ CREM $\alpha$} & \multirow[t]{2}{*}{ CREMT $_{2} \alpha$} \\
\hline & & & & & \\
\hline & chromosome 1 open reading frame 15 & AF288395.1 & $3.9 \uparrow$ & & $6.5 \uparrow$ \\
\hline LAMB3 & laminin, beta 3 & L25541.1 & $3.6 \uparrow$ & - & $3.9 \uparrow$ \\
\hline IL-17RC & interleukin 17 receptor $\mathrm{C}$ & BF112057 & $3.4 \uparrow$ & - & $3.8 \uparrow$ \\
\hline TSSC3 & tumor suppressing subtransferable candidate 3 & AF001294.1 & $3.3 \uparrow$ & - & $6.6 \uparrow$ \\
\hline CD86 & CD86 antigen (CD28 antigen ligand 2, B7-2 antigen) & L25259.1 & $3.3 \uparrow$ & - & $2.8 \uparrow$ \\
\hline ALK & anaplastic Iymphoma kinase (Ki-1) & U66559.1 & $3.2 \uparrow$ & - & $3.2 \uparrow$ \\
\hline FER & $\begin{array}{l}\text { fer (fps/fes related) tyrosine kinase (phosphoprotein } \\
\text { NCP94) }\end{array}$ & NM_005246 & $3.1 \uparrow$ & - & $3.5 \uparrow$ \\
\hline GJB3 & gap junction protein, beta 3, 31kDa (connexin 31) & AF099730 & $3.1 \uparrow$ & - & $3.7 \uparrow$ \\
\hline $\begin{array}{l}\text { DKFZP434G22 } \\
26\end{array}$ & 2 hypothetical protein DKFZp434G2226 & NM_031217 & $3.0 \uparrow$ & - & $2.2 \uparrow$ \\
\hline SGT & $\begin{array}{l}\text { small glutamine-rich tetratricopeptide repeat (TPR)- } \\
\text { containing }\end{array}$ & NM_003021 & $3.0 \uparrow$ & - & $3.5 \uparrow$ \\
\hline CDKN2A & $\begin{array}{l}\text { cyclin-dependent kinase inhibitor } 2 \mathrm{~A} \text { (melanoma, } \mathrm{p} 16 \text {, } \\
\text { inhibits CDK4) }\end{array}$ & U38945.1 & $2.9 \uparrow$ & - & $3.5 \uparrow$ \\
\hline SNRPD1 & small nuclear ribonucleoprotein D1 polypeptide $16 \mathrm{kDa}$ & NM_006938 & $2.7 \uparrow$ & - & $2.5 \uparrow$ \\
\hline $\mathrm{F} 3$ & coagulation factor III (thromboplastin, tissue factor) & NM_001993 & $2.7 \uparrow$ & - & $2.3 \uparrow$ \\
\hline SLC16A4 & $\begin{array}{l}\text { solute carrier family } 16 \text { (monocarboxylic acid } \\
\text { transporters), member } 4\end{array}$ & NM_004696 & $2.6 \uparrow$ & - & $4.1 \uparrow$ \\
\hline KRAS2 & $\mathrm{v}$-Ki-ras2 Kirsten rat sarcoma 2 viral oncogene homolog & gBF673699 & $2.6 \uparrow$ & - & $2.7 \uparrow$ \\
\hline SCN2B & sodium channel, voltage-gated, type II, beta polypeptide & eU87555.1 & $2.6 \uparrow$ & - & $4.4 \uparrow$ \\
\hline NQO1 & $\operatorname{NAD}(P) H$ dehydrogenase, quinone 1 & NM_000903 & $2.4 \uparrow$ & 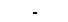 & $4.6 \uparrow$ \\
\hline ADH1A & alcohol dehydrogenase $1 \mathrm{~A}$ (class I), alpha polypeptide & NM_000667 & $2.4 \uparrow$ & - & $2.9 \uparrow$ \\
\hline RPL29 & ribosomal protein L29 & AW582267 & $2.4 \uparrow$ & - & $2.2 \uparrow$ \\
\hline SDHA & $\begin{array}{l}\text { succinate dehydrogenase complex, subunit } \mathrm{A} \text {, } \\
\text { flavoprotein }(\mathrm{Fp})\end{array}$ & NM_004168 & $2.4 \uparrow$ & - & $3.1 \uparrow$ \\
\hline PPP1R7 & protein phosphatase 1 , regulatory subunit 7 & Al090331 & $2.3 \uparrow$ & - & $4.7 \uparrow$ \\
\hline S100A7 & S100 calcium binding protein A7 (psoriasin 1) & NM_002963 & $2.3 \uparrow$ & 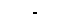 & $4.7 \uparrow$ \\
\hline GLRX & glutaredoxin (thioltransferase) & NM_002064 & $2.3 \uparrow$ & - & $2.7 \uparrow$ \\
\hline HUS1 & HUS1 checkpoint homolog (S. pombe) & Al968626 & $2.3 \uparrow$ & - & $2.9 \uparrow$ \\
\hline ANXA2P2 & annexin A2 pseudogene 2 & M62898.1 & $2.3 \uparrow$ & - & $3.4 \uparrow$ \\
\hline EIF2S1 & $\begin{array}{l}\text { eukaryotic translation initiation factor } 2 \text {, subunit } 1 \text { alpha, } \\
35 \mathrm{kDa}\end{array}$ & NM_004094 & $2.3 \uparrow$ & - & $2.6 \uparrow$ \\
\hline PSMC3 & $\begin{array}{l}\text { proteasome (prosome, macropain) } 26 \mathrm{~S} \text { subunit, } \\
\text { ATPase, } 3\end{array}$ & AL545523 & $2.2 \uparrow$ & - & $2.3 \uparrow$ \\
\hline F-LAN-1 & CGI-101 protein & NM_016041 & $2.2 \uparrow$ & - & $2.6 \uparrow$ \\
\hline HFL-EDDG1 & erythroid differentiation and denucleation factor 1 & NM_006553 & $2.1 \uparrow$ & - & $2.4 \uparrow$ \\
\hline SEMA5A & $\begin{array}{l}\text { sema domain, seven thrombospondin repeats (type } 1 \\
\text { and type } 1 \text {-like), transmembrane domain (TM) and shor } \\
\text { cytoplasmic domain, (semaphorin) 5A }\end{array}$ & NM_003966 & $2.1 \uparrow$ & - & $2.3 \uparrow$ \\
\hline ADRB2 & adrenergic, beta-2-, receptor, surface & NM_000024 & $2.0 \uparrow$ & - & $3.0 \uparrow$ \\
\hline \multirow[t]{2}{*}{ HT010 } & uncharacterized hypothalamus protein $\mathrm{HT} 010$ & AV7̄16798 & $2.0 \uparrow$ & - & $2.2 \uparrow$ \\
\hline & $\begin{array}{l}\text { Homo sapiens mRNA full length insert cDNA clone } \\
\text { EUROIMAGE } 1977059 \text { mRNA sequence }\end{array}$ & NM_003107 & $2.2+$ & - & $3.7+$ \\
\hline \multirow[t]{6}{*}{ RARRES 1} & retinoic acid receptor responder (tazarotene induced) 1 & NM_002888 & $2.7 \downarrow$ & - & $14.7 !$ \\
\hline & $\begin{array}{l}\text { Homo sapiens mRNA full length insert cDNA clone } \\
\text { EUROIMAGE } 46866 \text { mRNA sequence }\end{array}$ & AL 109674.1 & $2.7 \downarrow$ & - & $6.7 \downarrow$ \\
\hline & $\begin{array}{l}\text { Homo sapiens cDNA FLJ12683 fis, clone } \\
\text { NT2RM4002457, mRNA sequence }\end{array}$ & AA827892 & $2.7 \downarrow$ & - & $3.4+$ \\
\hline & ESTs & AW974666 & $2.9 \downarrow$ & - & $4.5 \downarrow$ \\
\hline & Homo sapiens clone 24566 mRNA sequence & AF070536.1 & $3.4 \downarrow$ & 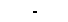 & $5.0 \mathrm{t}$ \\
\hline & $\begin{array}{l}\text { Homo sapiens cDNA FLJ14113 fis, clone } \\
\text { MAMMA1001715, mRNA sequence }\end{array}$ & AK024175.1 & $3.7 \downarrow$ & - & $3.0 \mathrm{t}$ \\
\hline GGA2 & $\begin{array}{l}\text { golgi associated, gamma adaptin ear containing, ARF } \\
\text { binding protein } 2\end{array}$ & Al799984 & $3.8 \downarrow$ & - & $5.4 \downarrow$ \\
\hline CDK10 & cyclin-dependent kinase (CDC2-like) 10 & NM_003674 & $4.5 \downarrow$ & - & $2.9 \downarrow$ \\
\hline JAM2 & junctional adhesion molecule 2 & NM_021219 & $4.5 \downarrow$ & - & $6.8 \downarrow$ \\
\hline TRG@ & $T$ cell receptor gamma locus & M30894.1 & $5.6 \downarrow$ & - & $4.8 \mathrm{t}$ \\
\hline \multirow[t]{3}{*}{ FMOD } & fibromodulin & NM_002023 & $5.9 \downarrow$ & - & $8.8 \mathrm{\downarrow}$ \\
\hline & $\begin{array}{l}\text { Homo sapiens mRNA; cDNA DKFZp564H1916 (from } \\
\text { clone DKFZp564H1916), mRNA sequence }\end{array}$ & AL110126.1 & $6.3 \downarrow$ & - & $8.8 \mathrm{t}$ \\
\hline & $\begin{array}{l}\text { Homo sapiens mRNA; cDNA DKFZp566F1224 (from } \\
\text { clone DKFZp566F1224), mRNA sequence }\end{array}$ & AL050032.1 & $6.3 \downarrow$ & - & $4.2+$ \\
\hline CD1D & CD1D antigen, $d$ polypeptide & NM_001766 & $7.7 \downarrow$ & - & $2.4+$ \\
\hline HPIP & hematopoietic PBX-interacting protein & BF 344265 & $10.0 \downarrow$ & - & $6.0 \mathrm{t}$ \\
\hline CCL15 & chemokine (C-C motif) ligand 15 & AF031587.1 & $12.5 \downarrow$ & - & $10.1 \downarrow$ \\
\hline AF15Q14 & AF15q14 protein & NM_020380 & $16.7 \downarrow$ & - & $6.3+$ \\
\hline & Gene & Genbank & CREB & CREM $\alpha$ & CREMT $_{2} \mathrm{O}$ \\
\hline \multicolumn{6}{|c|}{ Genes affected by CREM $\alpha$ \& CREMT $_{2} \alpha$} \\
\hline GPR30 & G protein-coupled receptor 30 & U63917.1 & - & $4.3 \uparrow$ & $10.7 \uparrow$ \\
\hline NAP1L1 & nucleosome assembly protein 1 -like 1 & BC002387.1 & - & $2.4 \uparrow$ & $2.2 \uparrow$ \\
\hline SUCLG1 & succinate-CoA ligase, GDP-forming, alpha subunit & NM_003849 & . & $2.2 \uparrow$ & $2.9 \uparrow$ \\
\hline OSTF1 & osteoclast stimulating factor & NM_012383 & - & $2.1 \uparrow$ & $2.3 \uparrow$ \\
\hline $\mathrm{CDC} 2 \mathrm{~L} 2$ & cell division cycle 2-like 2 & U 04819.1 & - & $2.0 \uparrow$ & $2.3 \uparrow$ \\
\hline DKFZP58611 & 1 DKFZP5861111 protein & AL050131.1 & . & $2.4 \downarrow$ & $2.1 \downarrow$ \\
\hline & & BF229395 & - & $2.5 \downarrow$ & $2.2 \downarrow$ \\
\hline KRT7 & keratin 7 & Al920979 & & $4.0 \downarrow$ & $4.8 \downarrow$ \\
\hline
\end{tabular}

Figure 4 (b).

Figure 4 (a) Overlap between the groups of genes regulated by CREB, CREM $\alpha$ and CREM $\tau_{2} \alpha$ : almost exactly one-third of the genes affected by CREM $\tau_{2} \alpha$ are also affected by CREB, and the same is true for CREM $\alpha$. The genes that are commonly affected by CREB and CREM $\tau_{2} \alpha$ do differ markedly from those commonly affected by CREB and CREM $\alpha$, however, and the proportion of genes commonly affected by the CREM $\tau_{2} \alpha$ and CREM $\alpha$ proteins is only $13 \%$ and just under $7 \%$ of the totals respectively. In summary, the majority of genes affected by these transcription factors belong to discrete groups, and are affected by one factor only. (b) A number of genes had their levels of expression altered by more than one of the CREB, CREM $\alpha$ and CREM $\tau_{2} \alpha$ factors. These genes were classified with respect to which of these factors affected their expression, and are grouped accordingly in the above table. The three columns on the right of each panel indicate the degree of up- or down-regulation in CREB, CREM $\alpha$ and $\mathrm{CREM} \tau_{2} \alpha$ stably transfected cell lines compared with the previously derived baseline expression levels; for example, $3.5 \uparrow$ denotes a $3 \cdot 5$-fold increase in gene expression. In the majority of cases these values are similar for each specific gene, although there are exceptions. The physiological relevance of this with reference to the temporal and spatial patterns of expression of the bZIP factors is discussed in the text. 


\begin{tabular}{|c|c|c|c|c|c|c|c|}
\hline \multirow[b]{2}{*}{ Gene } & \multirow[b]{2}{*}{$\begin{array}{l}\text { Discovered in } \\
\text { stably-transfected } \\
\text { cells expressing: }\end{array}$} & \multirow[b]{2}{*}{$\begin{array}{l}\text { Microarray } \\
\text { result: }\end{array}$} & \multicolumn{2}{|c|}{ Quantitative RT-PCRs } & \multicolumn{3}{|c|}{ Semi-Quantitative RT-PCRs } \\
\hline & & & $\begin{array}{l}\text { Stable } \\
\text { cells/control } \\
\text { cells }\end{array}$ & $\begin{array}{l}\text { NP tissue/P } \\
\text { tissue }\end{array}$ & $\begin{array}{l}\text { Vector } \\
\text { Vontrol } \\
\text { cells }\end{array}$ & $\begin{array}{c}\text { Stably- } \\
\text { transfected cells }\end{array}$ & $\mathbf{N P}$ \\
\hline MMP1 & CREB & $42.2 \uparrow$ & & & Eat & Nat & Exing \\
\hline PTPRB & CREB & $27.7 \uparrow$ & & & & $=$ & 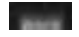 \\
\hline PRKCA & CREB & $8.7 \uparrow$ & $1.8 \pm 0.21 \uparrow$ & $2.5 \pm 0.30 \uparrow$ & - & 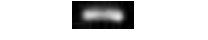 & $\mathrm{m}$ \\
\hline PLA2R1 & CREB & $12.9 \downarrow$ & & & 재영 & Exis & $\mathrm{Ex}$ \\
\hline CRSP8 & CREM $\alpha$ & $8.9 \uparrow$ & & & Em & Fint & $\mathrm{E}$ \\
\hline SMARCAL1 & 1 CREM $\alpha$ & $5.2 \uparrow$ & & & 댄 & $\square$ & \\
\hline CDKN1C & CREM $\alpha$ & $12.7 \downarrow$ & $7.9 \pm 0.25 \downarrow$ & $2.9 \pm 0.27 \uparrow$ & $m$ & $E$ & $\mathrm{mon}$ \\
\hline GPR30 & CREMT $_{2} \alpha$ & $4.3 \uparrow$ & & & 国 & Das & Las \\
\hline CDC42EP2 & $2 \mathrm{CREMT}_{2} \alpha$ & $5.1 \uparrow$ & & & 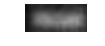 & $\square$ & $\Leftrightarrow$ \\
\hline FMOD & $\mathrm{CREMT}_{2} \alpha$ & $8.8 \downarrow$ & & & E: & E. & EM \\
\hline HUMNK1A & A CREMT $_{2} \alpha$ & $3.8 \downarrow$ & & & Ras & E: E. & $\Leftrightarrow$ \\
\hline
\end{tabular}

Figure $5 \mathrm{SQ}$ and quantitative RT-PCR was performed to verify differential expression of a random selection of genes revealed in the microarray analyses. Comparisons were made between (i) total RNA templates isolated from control empty-vector stably transfected cell lines and cell lines stably transfected with CREB, CREM $\alpha$ and CREM $\tau_{2} \alpha$ constructs, and (ii) mRNA templates isolated from pooled $(n=6)$ non-pregnant (NP) and pregnant non-labouring $(P)$ myometrial tissue samples. Details are given in the Materials and methods section. The level of expression in stably transfected cells compared with control cells reflected the results from the microarrays: those genes found to be up- or down-regulated by expression of the CREB and CREM factors by microarray analysis also showed increased or decreased expression respectively in the stable cell lines compared with control cells by RT-PCR. In addition, the expression of these genes was found to be significantly altered between the pooled NP and P tissue, reflecting the in vivo biological situation. Of the 11 genes examined, six were expressed to a greater degree in NP tissue compared with $\mathrm{P}$, four were expressed at a higher level in $\mathrm{P}$ tissue in comparison to NP, and one gene showed no significant difference in expression levels. Real-time RT-PCR analysis of two of these genes, PRKCA and CDKN1C, indicated significant upand down-regulation respectively of their expression in stable cell lines in accordance with the microarray data, and also increased expression in NP tissue compared with $\mathrm{P}$ tissue, reflecting the situation in vivo.

selection and not by the transfected factors themselves. In our hands, these manipulations affected the expression of 1317 genes $(5.9 \%$ of the total represented on the microarray chip) greater than or equal to $1 \cdot 5$-fold. This total does not seem excessive: similar studies have shown $16 \%$ of genes to be affected in this way (Mayanil et al. 2001). These genes were subtracted from the 22283 represented on the microarray chip, to give a final baseline of 20966 genes for our comparisons.

Rigorous statistical treatment of the resultant microarray data, in triplicate for each stable cell line, showed the expression of a total of 1296 genes to be affected by the three bZIP factors, representing $6 \cdot 2 \%$ of genes examined. CREB, the transcriptional activator whose myometrial expression we have found to be almost entirely arrested in the transition from the non-pregnant to the pregnant state, altered the expression of 958 genes; CREM $\alpha$, the transcriptional repressor completely absent from NP myometrium but up-regulated in $\mathrm{P}$ and labouring tissue, altered the expression of 118 genes; $\operatorname{CREM} \tau_{2} \alpha$, able to function as an activator and a repressor of transcription, affected the transcription of 220 genes. These results, confirmed via SQ RT-PCR/ real-time RT-PGR of RNA isolated from stably transfected cell lines and myometrial tissues of a panel of genes from the resultant gene lists, showed the altered expression of a wide variety of genes over a broad range of classifications known to be intrinsically involved in the development, control and overall function of the uterus and its component proteins and molecules. The 
most germane of these are listed in Fig. 3a, alongside appropriate citations of reports describing their particular involvement in uterine function. Pertinent examples to elaborate upon include the following. Regulator of G-protein signalling RGS2: responsive to oxytocin and progesterone; increases during pregnancy then falls again prior to labour in the rat. Prostaglandin F receptor: increases during pregnancy and again at onset of labour. Luteinizing hormone (LH)/human chorionic gonadotropin (hCG) and oxytocin receptors: temporally and spatially regulated in myometrium during pregnancy. Chemokines and cytokines: interleukin (IL)-1 $\beta$ increases in myometrium during pregnancy and negatively regulates oxytocin receptor; IL-8 increases during term labour; IL- $1 \beta$ and IL-6 increase myometrial oxytocin secretion; IL-1 and IL-8 receptors decrease as gestation progresses. Cytoskeletal proteins: supervillin mediates actin/myosin organization; tropomyosin- $1 \alpha$ is a component of actin filaments/myofibrils; CITED2 is a co-activator of AP-2. Collagens: nine different collagens were affected, some of which are known to be upregulated in the mouse myometrium during pregnancy. Protein kinases, including mitogen-activated protein kinases (MAPKs), cAMP-dependent protein kinases and three protein kinase $\mathrm{C}(\mathrm{PKG})$ isoforms thought to mediate endothelin-induced uterine contractions. Iontransport channels, thought to be important in augmenting uterine contractility in labour. Affected examples include the $\alpha 3$ sodium pump which decreases in human myometrium at labour, and ATP-sensitive potassium channels which decrease in pregnancy/ labour. Pregnancy-specific glycoproteins (PSGs) 3, 6 and 9, which regulate the production of anti-inflammatory cytokines. Calpain-10: calpains may facilitate nuclear factor $\kappa \mathrm{B}(\mathrm{NF}-\kappa \mathrm{B})$ translocation, cyclooxygenase expression and prostaglandin synthesis. Transient receptor potential channels (Trp): components of store-operated calcium entry (SOCE) channels that are involved in myometrial calcium homeostasis. Corticotropin-releasing hormone (CRH) receptors R1 and R2: CRH promotes myometrial quiescence via cAMP generation. CRH receptors are desensitized at term, and a contractile state ensues. Suppressor of cytokine signalling (SOCS) 1: SOCS proteins are differentially regulated in gestational tissues; reduction is associated with onset of labour. $\alpha 2$ and $\beta 2$ adrenoceptors: associated with contractile and relaxatory processes respectively. Prostaglandin receptors F, D2 (DP) and EP3: critical in the maintenance of pregnancy and initiation and progression of labour; differentially expressed in the myometrium and associated with regulation of cytokines.

In addition to the genes listed in Fig. 3a, many other genes affected by the expression of CREB, CREM $\alpha$ and CREM $\tau_{2} \alpha$ belonging to functional gene groups intimately involved in uterine function were found as a result of this investigation. These are listed in online supplementary Fig. 3b-e due to the fact that they have not yet been characterized in the human myometrium, though many of these genes may turn out to be of real importance in the regulation of myometrial contractility in the future.

By determining a genomic profile of the genes that are regulated by the over-expression of CREB/CREM transcription factors in myometrial cells, we have provided further evidence for their involvement in the regulation of myometrial gene expression and function during pregnancy. We have previously shown these factors to be differentially expressed in human myometrial tissues, with a dramatic switch between the expression of phosphorylated CREB transactivator in the non-pregnant state to the CREM $\alpha$ repressor isoform in the pregnant and particularly labouring states, with an accompanying steady reduction in the expression of the CREM $\tau_{2} \alpha$ transcriptional activator. Here we have shown that these factors alter the expression of a wide range of genes, many of which are or may be involved in the control of uterine growth and differentiation, and maintaining the balance between the contractile and relaxatory states of the myometrium throughout pregnancy and in labour. The three factors show a high degree of exclusivity in the downstream genes whose expression they affect (Fig. 4b) despite their ability to form heterodimers with common interaction partners from the bZIP transcription factor family, which suggests that some other complex-specific co-factors may be involved in their mechanisms of action.

The results presented here show a high degree of similarity to those from a similar study involving the closely related bZIP transcription factors and heterodimerization partners ATF2 and a novel splice variant ATF2-small, which are also differentially expressed in the human myometrium in a spatially as well as temporally dependent manner (Bailey et al. 2000, Bailey \& Europe-Finner 2004). Taken together, these findings demonstrate the importance of five interacting bZIP factors in controlling myometrial gene expression, much of which is linked to gestational physiological processes such as tissue, extracellular matrix and cytoskeletal remodelling, signal transduction, activity of cytokines, hormones and their receptors, and of course muscular contractility. They also highlight the importance of interplay between the MAPK pathways involved in ATF2 activation and activity, and the PKA pathways involved in GREB and CREM activity.

In conclusion, specific forms of the cAMP-responsive bZIP transcription factors (CREB, CREM $\alpha$ and $\left.\operatorname{CREM} \tau_{2} \alpha\right)$ have previously been shown by us to be temporally differentially expressed in the human myometrium throughout gestation, and to possess transactivation and trans-repression properties with regard to downstream genes containing CREs in their promoter regions. We show here that these potent factors act in 
human myometrial cells to affect the expression of genes with a wide range of roles attributable to uterine activity. This supports our hypothesis that the cAMP/PKA signalling pathway, acting via the cAMP-responsive transcription factors CREB, CREM $\alpha$ and CREM $\tau_{2} \alpha$, plays an important role in the control of uterine contractility during human pregnancy and labour.

\section{Acknowledgements}

This work was funded by a grant made available from the Wellcome Trust (grant 062928). We wish to thank Dr Heiko Peters and Miss Ilka Wappler of the Institute of Human Genetics (University of Newcastle upon Tyne), for making available the Affymetrix system and for technical expertise respectively. The authors declare that there is no conflict of interest that would prejudice the impartiality of this scientific work.

\section{References}

Al-Matubsi HY, Eis AL, Brodt-Eppley J, MacPhee DJ, Lye S \& Myatt L 2001 Expression and localization of the contractile prostaglandin $\mathrm{F}$ receptor in pregnant rat myometrium in late gestation, labor, and postpartum. Biology of Reproduction $\mathbf{6 5}$ 1029-1037.

Bailey J \& Europe-Finner GN 2004 Identification of human myometrial target genes of the cJun $\mathrm{NH}_{2}$-terminal kinase (JNK) pathway: the role of activating transcription factor 2 (ATF2) and a novel spliced isoform ATF2-small. Fournal of Molecular Endocrinology 34 19-35 (see this issue).

Bailey J, Sparey C, Phillips RJ, Gilmore K, Robson SC, Dunlop W \& Europe-Finner GN 2000 Expression of the cyclic AMP-dependent transcription factors, CREB, CREM and ATF2, in the human myometrium during pregnancy and labour. Molecular Human Reproduction 6 648-660.

Bailey J, Phillips RJ, Pollard AJ, Gilmore K, Robson SC \& Europe-Finner GN 2002 Characterization and functional analysis of cAMP response element modulator protein and activating transcription factor 2 (ATF2) isoforms in the human myometrium during pregnancy and labor: identification of a novel ATF2 species with potent transactivation properties. Fournal of Clinical Endocrinology and Metabolism 87 1717-1728.

Belt AR, Baldassare JJ, Molnar M, Romero R \& Hertelendy F 1999 The nuclear transcription factor NF-kappaB mediates interleukin-1 beta-induced expression of cyclooxygenase-2 in human myometrial cells. American Fournal of Obstetrics and Gynecology $181359-366$.

Blumenstein M, Bowen-Shauver JM, Keelan JA \& Mitchell MD 2002 Identification of suppressors of cytokine signaling (SOCS) proteins in human gestational tissues: differential regulation is associated with the onset of labor. Fournal of Clinical Endocrinology and Metabolism 87 1094-1097.

Borrelli E, Montmayeur JP, Foulkes NS \& Sassone-Corsi P 1992 Signal transduction and gene control: the cAMP pathway. Critical Reviewes in Oncogenesis 3 321-338.

Bowen JM, Chamley L, Keelan JA \& Mitchell MD 2002 Cytokines of the placenta and extra-placental membranes: roles and regulation during human pregnancy and parturition. Placenta $\mathbf{2 3}$ $257-273$
Chen Y, Takizawa N, Crowley JL, Oh SW, Gatto CL, Kambara T, Sato O, Li XD, Ikebe M \& Luna EJ 2003 F-actin and myosin II binding domains in supervillin. Fournal of Biological Chemistry 278 $46094-46106$.

Curley M, Cairns MT, Friel AM, McMeel OM, Morrison JJ \& Smith TJ 2002 Expression of mRNA transcripts for ATP-sensitive potassium channels in human myometrium. Molecular Human Reproduction 8 941-945.

Dalrymple A, Slater DM, Beech D, Poston L \& Tribe RM 2002 Molecular identification and localization of Trp homologues, putative calcium channels, in pregnant human uterus. Molecular Human Reproduction 8 946-951.

De Cesare D, Fimia GM \& Sassone-Corsi P 1999 Signaling routes to CREM and CREB: plasticity in transcriptional activation. Trends in Biochemical Sciences 24 281-285.

de Groot RP, den Hertog J, Vandenheede JR, Goris J \& Sassone-Corsi P 1993 Multiple and cooperative phosphorylation events regulate the CREM activator function. EMBO Fournal 12 3903-3911.

Don J \& Stelzer G 2002 The expanding family of CREB/CREM transcription factors that are involved with spermatogenesis. Molecular and Cellular Endocrinology 187 115-124.

Dong YL, Fang L, Kondapaka S, Gangula PR, Wimalawansa J \& Yallampalli C 1999 Involvement of calcitonin gene-related peptide in the modulation of human myometrial contractility during pregnancy. Foumal of Clinical Investigation 104 559-565.

Dumin J, Wilcox BD, Otterness I, Melendez JA, Huang C \& Jeffrey JJ 1998 Serotonin-mediated production of interstitial collagenase by uterine smooth muscle cells requires interleukin-1 alpha, but not interleukin-1 beta. Fournal of Biological Chemistry 273 25488-25494.

Dziadek M, Darling P, Zhang RZ, Pan TC, Tillet E, Timpl R \& Chu ML 1995 Expression of collagen alpha 1(VI), alpha 2(VI), and alpha $3(\mathrm{VI})$ chains in the pregnant mouse uterus. Biology of Reproduction 52 885-894.

Elliott CL, Slater DM, Dennes W, Poston L \& Bennett PR 2000 Interleukin 8 expression in human myometrium: changes in relation to labor onset and with gestational age. American fournal of Reproductive Immunology 43 272-277.

Esplin MS, Fausett MB, Faux DS \& Graves SW 2003 Changes in the isoforms of the sodium pump in the placenta and myometrium of women in labor. American Fournal of Obstetrics and Gynecology 188 759-764.

Eude I, Paris B, Cabrol D, Ferre F \& Breuiller-Fouche M 2000 Selective protein kinase $\mathrm{C}$ isoforms are involved in endothelin-1-induced human uterine contraction at the end of pregnancy. Biology of Reproduction 63 1567-1573.

Europe-Finner GN, Phaneuf S, Watson SP \& Lopez Bernal A 1993 Progesterone and estradiol concentrations in nonpregnant and pregnant human myometrium. Effect of progesterone and estradiol on cyclic adenosine monophosphate-phosphodiesterase activity. Endocrinology $1322484-2490$.

Europe-Finner GN, Phaneuf S, Tolkovsky AM, Watson SP \& Lopez Bernal A 1994 Down-regulation of G alpha s in human myometrium in term and preterm labor: a mechanism for parturition. Fournal of Clinical Endocrinology and Metabolism 79 $1835-1839$.

Fentzke RC, Korcarz CE, Lang RM, Lin H \& Leiden JM 1998 Dilated cardiomyopathy in transgenic mice expressing a dominant-negative CREB transcription factor in the heart. Fournal of Clinical Investigation 101 2415-2426.

Foulkes NS \& Sassone-Corsi P 1992 More is better: activators and repressors from the same gene. Cell 68 411-414.

Frauli M \& Ludwig H 1987 Inhibition of fibroblast proliferation in a culture of human endometrial stromal cells using a medium containing D-valine. Archives of Gynecology and Obstetrics 241 87-96.

Friebe-Hoffmann U, Chiao JP \& Rauk PN 2001 Effect of IL-1 beta and IL- 6 on oxytocin secretion in human uterine smooth muscle cells. American Fournal of Reproductive Immunology 46 226-231. 
Fuchs A, Fuchs F, Husslein P \& Soloff M 1984 Oxytocin receptors in the human uterus during pregnancy and parturition. American Journal of Obstetrics and Gynecology $150734-741$.

Gibellini D, Re MC, La Placa M \& Zauli G 2002 Differentially expressed genes in HIV-1 tat-expressing CD4(+) T-cell line. Virus Research 90 337-345.

Gilbert SF \& Migeon BR 1975 D-valine as a selective agent for normal human and rodent epithelial cells in culture. Cell 5 11-17.

Gilbert SF \& Migeon BR 1977 Renal enzymes in kidney cells selected by D-valine medium. Fournal of Cellular Physiology 92 $161-167$.

Gonzalez GA \& Montminy MR 1989 Cyclic AMP stimulates somatostatin gene transcription by phosphorylation of CREB at serine 133. Cell $\mathbf{5 9}$ 675-680.

Goranova V, Vizza E \& Motta PM 1993 Collagen fibrillar network in estrous and hCG-stimulated rabbit uterus: a SEM study after $\mathrm{NaOH}$ maceration. Archives of Histology and Cytology 56 231-241.

Grammatopoulos DK \& Hillhouse EW 1999 Activation of protein kinase $\mathrm{C}$ by oxytocin inhibits the biological activity of the human myometrial corticotropin-releasing hormone receptor at term. Endocrinology 140 585-594.

Habener JF, Miller CP \& Vallejo M 1995 cAMP-dependent regulation of gene transcription by cAMP response element-binding protein and cAMP response element modulator. Vitamins and Hormones 51 1-57.

Hai T \& Curran T 1991 Cross-family dimerization of transcription factors Fos/Jun and ATF/CREB alters DNA binding specificity. PNAS 88 3720-3724.

Hai T, Liu F, Coukos WJ \& Green MR 1989 Transcription factor ATF cDNA clones: an extensive family of leucine zipper proteins able to selectively form DNA-binding heterodimers. Genes and Development 3 2083-2090 [Erratum. Genes and Development 19904 682].

Hatthachote P \& Gillespie JI 1999 Complex interactions between sex steroids and cytokines in the human pregnant myometrium: evidence for an autocrine signaling system at term. Endocrinology $1402533-2540$.

Haus-Seuffert P \& Meisterernst M 2000 Mechanisms of transcriptional activation of cAMP-responsive element-binding protein CREB. Molecular and Cellular Biochemistry 212 5-9.

Helmer H, Tretzmuller U, Brunbauer M, Kaider A, Husslein P \& Knofler M 2002 Production of oxytocin receptor and cytokines in primary uterine smooth muscle cells cultivated under inflammatory conditions. Fournal of the Society for Gynecologic Investigation 9 15-21.

Hongpaisan J 2000 Inhibition of proliferation of contaminating fibroblasts by $\mathrm{D}$-valine in cultures of smooth muscle cells from human myometrium. Cell Biology International Reports 24 1-7.

Honore LH, Salkie ML \& Jajczay FL 1986 The influence of anatomical site and hormonal status on the copper and zinc levels of human uterine smooth muscle. Clinical Biochemistry 19 46-48.

Katoh Y, Molkentin JD, Dave V, Olson EN \& Periasamy M 1998 MEF2B is a component of a smooth muscle-specific complex that binds an A/T-rich element important for smooth muscle myosin heavy chain gene expression. Fournal of Biological Chemistry 273 1511-1518.

Keelan JA, Blumenstein M, Helliwell RJA, Sato TA, Marvin KW \& Mitchell MD 2003 Cytokines, prostaglandins and parturition-a review. Placenta 24 (suppl. A) Trophoblast Research 17 S33-S46.

Kelly RW \& Abel MH 1983 Copper and zinc inhibit the metabolism of prostaglandin by the human uterus. Biology of Reproduction 28 883-889.

Kofinas AD, Rose JC, Koritnik DR \& Meis PJ 1990 Progesterone and estradiol concentrations in nonpregnant and pregnant human myometrium. Effect of progesterone and estradiol on cyclic adenosine monophosphate-phosphodiesterase activity. Fournal of Reproductive Medicine 35 1045-1050.
Landschulz WH, Johnson PF \& McKnight SL 1988 The leucine zipper: a hypothetical structure common to a new class of DNA binding proteins. Science 240 1759-1764.

Lopez Bernal A, Europe-Finner GN, Phaneuf S \& Watson SP 1995 Preterm labour: a pharmacological challenge. Trends in Pharmacological Sciences 16 129-133.

Ma C \& Chegini N 1999 Regulation of matrix metalloproteinases (MMPs) and their tissue inhibitors in human myometrial smooth muscle cells by TGF-betal. Molecular Human Reproduction 5 950-954.

Mayanil CS, George D, Freilich L, Miljan EJ, Mania-Farnell B, McLone DG \& Bremer EG 2001 Microarray analysis detects novel Pax3 downstream target genes. Fournal of Biological Chemistry $27649299-49309$.

Moonen P, Klok G \& Keirse MJ 1986 Distribution of prostaglandin endoperoxide synthase and prostacyclin synthase in the late pregnant uterus. British Fournal of Obstetrics and Gynaecology 93 255-259.

Morrison JJ, Dearn SR, Smith SK \& Ahmed A 1996 Activation of protein kinase $\mathrm{C}$ is required for oxytocin-induced contractility in human pregnant myometrium. Human Reproduction 11 2285-2290.

Muller FU, Boknik P, Knapp J, Neumann J, Vahlensieck U, Oetjen E, Scheld HH \& Schmitz W 1998 Identification and expression of a novel isoform of cAMP response element modulator in the human heart. FASEB fournal 12 1191-1199.

Murugesan K, Vij U, Lal B \& Farooq A 1989 Effect of progestins, estradiol, and coenzymes NAD and NADPH on the interconversion of estradiol and estrone in rabbit uterus in vitro. Steroids $\mathbf{5 3}$ 695-712.

Nishinaka K \& Fukuda Y 1991 Changes in extracellular matrix materials in the uterine myometrium of rats during pregnancy and postparturition. Acta Pathologica Faponica 41 122-132.

Osman I, Young A, Ledingham MA, Thomson AJ, Jordan F, Greer IA \& Norman JE 2003 Leukocyte density and pro-inflammatory cytokine expression in human fetal membranes, decidua, cervix and myometrium before and during labour at term. Molecular Human Reproduction 9 41-45.

Ou CW, Chen ZQ Qi S \& Lye SJ 2000 Expression and regulation of the messenger ribonucleic acid encoding the prostaglandin $\mathrm{F}(2$ alpha) receptor in the rat myometrium during pregnancy and labor. American Fournal of Obstetrics and Gynecology 182 919-925.

Park ES, Echetebu CO, Soloff S \& Soloff MS 2002 Oxytocin stimulation of RGS2 mRNA expression in cultured human myometrial cells. American Foumal of Physiology Endocrinology and Metabolism 282 E580-E584.

Prakash SK, Paylor R, Jenna S, Lamarche-Vane N, Armstrong DL, Xu B, Mancini MA \& Zoghbi HY 2000 Functional analysis of ARHGAP6, a novel GTPase-activating protein for RhoA. Human Molecular Genetics 9 477-488.

Rauk PN, Friebe-Hoffmann U, Winebrenner LD \& Chiao JP 2001 Interleukin-6 up-regulates the oxytocin receptor in cultured uterine smooth muscle cells. Fournal of Clinical Endocrinology and Metabolism 87 2435-2441.

Saalbach A, Aust G, Haustein UF, Herrmann K \& Anderegg U 1997 The fibroblast-specific MAb AS02: a novel tool for detection and elimination of human fibroblasts. Cell and Tissue Research 290 593-599.

Sanborn BM $2000 a$ Increasing the options-new 3',5' cyclic adenosine monophosphate (cAMP)-responsive promoters and new exons in the cAMP response element modulator gene. Endocrinology $1413921-3922$.

Sanborn BM 2000b Relationship of ion channel activity to control of myometrial calcium. Fournal of the Society for Gynecologic Investigation $\mathbf{7}$ 4-11.

Sanborn BM, Millan JL \& Meistrich ML 1997 Alternative splicing of CREB and CREM mRNAs in an immortalized germ cell line. fournal of Andrology 18 62-70.

Sassone-Corsi P 1988 Cyclic AMP induction of early adenovirus promoters involves sequences required for E1A trans-activation. PNAS 85 7192-7196. 
Sassone-Corsi P 1998 Coupling gene expression to cAMP signalling: role of CREB and CREM. International Fournal of Biochemistry and Cell Biology 30 27-38.

Schmid B, Wong S \& Mitchell BF 2001 Transcriptional regulation of oxytocin receptor by interleukin-1 beta and interleukin-6. Endocrinology 142 1380-1385.

Servillo G, Della Fazia MA \& Sassone-Corsi P 2002 Coupling cAMP signaling to transcription in the liver: pivotal role of CREB and CREM. Experimental Cell Research 275 143-154.

Snyder SK, Wessner DH, Wessells JL, Waterhouse RM, Wahl LM, Zimmermann W \& Dveksler GS 2001 Pregnancy-specific glycoproteins function as immunomodulators by inducing secretion of IL-10, IL-6 and TGF-betal by human monocytes. American Fournal of Reproductive Immunology 45 205-216.

Sordillo LM, Oliver SP \& Akers RM 1988 Culture of bovine mammary epithelial cells in D-valine modified medium: selective removal of contaminating fibroblasts. Cell Biology International Reports 12 355-364.

Sparey C, Robson SG, Bailey J, Lyall F \& Europe-Finner GN 1999 The differential expression of myometrial connexin-43, cyclooxygenase- 1 and -2 , and Gs alpha proteins in the upper and lower segments of the human uterus during pregnancy and labor. Journal of Clinical Endocrinology and Metabolism 84 1705-1710.

Sperelakis N, Inoue Y \& Ohya Y 1992 Fast Na+ channels and slow $\mathrm{Ca} 2+$ current in smooth muscle from pregnant rat uterus. Fapanese fournal of Pharmacology 58 (suppl. 2) 96P-106P.

Suarez VR, Park ES, Hankins GD \& Soloff MS 2003 Expression of regulator of $\mathrm{G}$ protein signaling-2 in rat myometrium during pregnancy and parturition. American Fournal of Obstetrics and Gynecology 188 973-977.

Sun P, Schoderbek WE \& Maurer RA 1992 Phosphorylation of cyclic adenosine $3^{\prime}, 5^{\prime}$-monophosphate (cAMP) response element-binding protein isoforms by the cAMP-dependent protein kinase. Molecular Endocrinology 6 1858-1866.

Taylor CV, Letarte M \& Lye SJ 1996 The expression of integrins and cadherins in normal human uterus and uterine leiomyomas. American Fournal of Obstetrics and Gynecology 175 411-419.

Terpe HJ, Stark H, Ruiz P \& Imhof BA 1994 Alpha 6 integrin distribution in human embryonic and adult tissues. Histochemistry $10141-49$.
Toro L, Ramos-Franco J \& Stefani E 1990 GTP-dependent regulation of myometrial $\mathrm{KCa}$ channels incorporated into lipid bilayers. Fournal of General Physiology 96 373-394.

Tribe RM, Moriarty P, Dalrymple A, Hassoni AA \& Poston L 2003 Interleukin- 1 beta induces calcium transients and enhances basal and store operated calcium entry in human myometrial smooth muscle. Biology of Reproduction 68 1842-1849.

Walker WH, Sanborn BM \& Habener JF 1994 An isoform of transcription factor CREM expressed during spermatogenesis lacks the phosphorylation domain and represses cAMP-induced transcription. PNAS 91 12423-12427.

Walker WH, Girardet C \& Habener JF 1996 Alternative exon splicing controls a translational switch from activator to repressor isoforms of transcription factor CREB during spermatogenesis. Fournal of Biological Chemistry 271 20145-21050.

Weston G, Trajstman AC, Gargett GE, Manuelpillai U, Vollenhoven BJ \& Rogers PA 2003 Fibroids display an anti-angiogenic gene expression profile when compared with adjacent myometrium. Molecular Human Reproduction 9 541-549.

White MT, Hu AS, Hamamoto ST \& Nandi S 1978 In vitro analysis of proliferating epithelial cell populations from the mouse mammary gland: fibroblast-free growth and serial passage. In Vitro 14 271-281.

Xie T, Belinsky M, Xu Y \& Jaiswal AK 1995 J ARE- and TREmediated regulation of gene expression. Response to xenobiotics and antioxidants. Fournal of Biological Chemistry $2706894-6900$.

Yang X, Lee Sr FY \& Wand GS 1997 Increased expression of Gs(alpha) enhances activation of the adenylyl cyclase signal transduction cascade. Molecular Endocrinology 11 1053-1061.

Ziff EB 1990 Transcription factors: a new family gathers at the cAMP response site. Trends in Genetics 6 69-72.

Zuo J, Lei ZM \& Rao CV 1994 Human myometrial chorionic gonadotropin/luteinizing hormone receptors in preterm and term deliveries. Fournal of Clinical Endocrinology and Metabolism 79 907-911.

Received 1 October 2004 Accepted 19 October 2004

Made available online as an Accepted Preprint 1 November 2004 